\title{
THE
}

3-19-2015

\section{Carbon Dynamics of the Weddell Gyre, Southern Ocean}

Peter J. Brown

Loïc Jullion

Peter Landschützer

Dorothee C.E. Bakker

Alberto C. Naveira Garabato

See next page for additional authors

Follow this and additional works at: https://digitalcommons.uri.edu/gsofacpubs Creative Commons License

\section{(c) (7)}

This work is licensed under a Creative Commons Attribution 4.0 License.

\section{Citation/Publisher Attribution}

Peter J. Brown, Loic Jullion, Peter Landschutzer, Dorothee C.E. Bakker, Alberto C. Naveira Garabato, Michael P. Meredith, Sinhue Torres-Valdes, Andrew Watson, Mario Hoppema, Brice Loose, Elizabeth M. Jones, Maciej Telszewski, Steve D. Jones, and Rik Wanninkhof. (2015). "Carbon dynamics of the Weddell Gyre, Southern Ocean." Global Biogeochemical Cycles, 29(3), 288-306.

Available at: http://onlinelibrary.wiley.com/doi/10.1002/2014GB005006/full

This Article is brought to you for free and open access by the Graduate School of Oceanography at DigitalCommons@URI. It has been accepted for inclusion in Graduate School of Oceanography Faculty Publications by an authorized administrator of DigitalCommons@URI. For more information, please contact digitalcommons-group@uri.edu. 


\section{Authors}

Peter J. Brown, Loïc Jullion, Peter Landschützer, Dorothee C.E. Bakker, Alberto C. Naveira Garabato, Michael P. Meredith, Sinhue Torres-Valdés, Andrew J. Watson, Mario Hoppema, Brice Loose, Elizabeth M. Jones, Maciej Telszewski, Steve D. Jones, and Rik Wanninkhof 


\section{Global Biogeochemical Cycles}

\section{RESEARCH ARTICLE}

10.1002/2014GB005006

Key Points:

- Three methods used to constrain air-sea $\mathrm{CO}_{2}$ fluxes in the region of Southern Ocean

- All show Weddell Gyre a strong summer $\mathrm{CO}_{2}$ sink and winter source to the atmosphere

- Carbon dynamics sensitive to oceanic vertical and horizontal circulation

Correspondence to:

P. J. Brown,

brown.pj@gmail.com

Citation:

Brown, P. J., et al. (2015), Carbon dynamics of the Weddell Gyre, Southern Ocean, Global Biogeochem. Cycles, 29, 288-306, doi:10.1002/2014GB005006.

Received 6 OCT 2014

Accepted 15 FEB 2015

Accepted article online 19 FEB 2015

Published online 19 MAR 2015

\section{Carbon dynamics of the Weddell Gyre, Southern Ocean}

\author{
Peter J. Brown ${ }^{1,2,3}$, Loïc Jullion ${ }^{4,5}$, Peter Landschützer ${ }^{1,6}$, Dorothee C. E. Bakker ${ }^{1}$, \\ Alberto C. Naveira Garabato ${ }^{4}$, Michael P. Meredith ${ }^{2,7}$, Sinhue Torres-Valdés ${ }^{3}$, Andrew J. Watson ${ }^{8}$, \\ Mario Hoppema ${ }^{9}$, Brice Loose ${ }^{10}$, Elizabeth M. Jones ${ }^{11,12}$, Maciej Telszewski ${ }^{13}$, Steve D. Jones ${ }^{14}$, \\ and Rik Wanninkhof ${ }^{15}$
}

${ }^{1}$ Centre for Ocean and Atmospheric Sciences, School of Environmental Sciences, University of East Anglia, Norwich, UK, ${ }^{2}$ British Antarctic Survey, Cambridge, UK, ${ }^{3}$ National Oceanography Centre, Southampton, UK, ${ }^{4}$ National Oceanography Centre, University of Southampton, Southampton, UK, ${ }^{5}$ Mediterranean Institute of Oceanography, Aix-Marseille University, CNRS/INSU, IRD, MIO, UM 110, Marseille, France, ${ }^{6}$ Institute of Biogeochemistry and Pollutant Dynamics, ETH Zürich, Zürich, Switzerland, ${ }^{7}$ Scottish Association for Marine Science, Oban, UK, ${ }^{8}$ College of Life and Environmental Sciences, University of Exeter, Exeter, UK, ${ }^{9}$ Alfred Wegener Institute Helmholtz Centre for Polar and Marine Research, Bremerhaven, Germany, ${ }^{10}$ Graduate School of Oceanography, University of Rhode Island, Narragansett, Rhode Island, USA, ${ }^{11}$ Royal Netherlands Institute for Sea Research (NIOZ), Texel, Netherlands, ${ }^{12}$ Centre for Energy and Environmental Sciences, Energy and Sustainability Research Institute Groningen, University of Groningen, Groningen, Netherlands, ${ }^{13}$ International Ocean Carbon Coordination Project, Institute of Oceanology of Polish Academy of Sciences, Sopot, Poland, ${ }^{14}$ Tyndall Centre for Climate Change Research, University of East Anglia, Norwich, UK, ${ }^{15}$ Ocean Chemistry Division, Atlantic Oceanographic and Meteorological Laboratory, National Oceanic and Atmospheric Administration, Miami, Florida, USA

Abstract The accumulation of carbon within the Weddell Gyre and its exchanges across the gyre boundaries are investigated with three recent full-depth oceanographic sections enclosing this climatically important region. The combination of carbon measurements with ocean circulation transport estimates from a box inverse analysis reveals that deepwater transports associated with Warm Deep Water (WDW) and Weddell Sea Deep Water dominate the gyre's carbon budget, while a dual-cell vertical overturning circulation leads to both upwelling and the delivery of large quantities of carbon to the deep ocean. Historical sea surface $p \mathrm{CO}_{2}$ observations, interpolated using a neural network technique, confirm the net summertime sink of 0.044 to $0.058 \pm 0.010 \mathrm{PgC} \mathrm{yr}^{-1}$ derived from the inversion. However, a wintertime outgassing signal similar in size results in a statistically insignificant annual air-to-sea $\mathrm{CO}_{2}$ flux of $0.002 \pm 0.007 \mathrm{Pg} \mathrm{Cyr}^{-1}$ (mean 1998-2011) to $0.012 \pm 0.024 \mathrm{Pg} \mathrm{Cyr}^{-1}$ (mean 2008-2010) to be diagnosed for the Weddell Gyre. A surface layer carbon balance, independently derived from in situ biogeochemical measurements, reveals that freshwater inputs and biological drawdown decrease surface ocean inorganic carbon levels more than they are increased by WDW entrainment, resulting in an estimated annual carbon sink of $0.033 \pm 0.021 \mathrm{PgC} \mathrm{yr}^{-1}$. Although relatively less efficient for carbon uptake than the global oceans, the summertime Weddell Gyre suppresses the winter outgassing signal, while its biological pump and deepwater formation act as key conduits for transporting natural and anthropogenic carbon to the deep ocean where they can reside for long time scales.

\section{Introduction}

The Southern Ocean $\left(>44^{\circ} \mathrm{S}\right)$ plays a critical role in the global carbon cycle as the location of both substantial anthropogenic carbon uptake ( $0.7 \mathrm{PgC} \mathrm{yr}^{-1}$, approximately a third of the total global oceanic sink [Khatiwala et al., 2009; Mikaloff Fletcher et al., 2006]) and outgassing of upwelled natural dissolved inorganic carbon (DIC) (0.4 $\mathrm{Pg} \mathrm{C} \mathrm{yr}^{-1}$ ) [Mikaloff Fletcher et al., 2007]. This is a consequence of its unique circulation: the lack of continental boundaries permits the existence of the Antarctic Circumpolar Current (ACC) that facilitates zonal exchange between the major ocean basins and meridionally allows the upwelling of DIC-rich Circumpolar Deep Water (CDW). The lighter components of this water mass merge with the ventilated mixed layer and move northward [Sallée et al., 2012], while denser classes are transported south where they can combine with colder, fresher surface waters and dense shelf waters, forming Antarctic Bottom Water (AABW) and closing the southern loop of the overturning circulation [Lumpkin and Speer, 2007]. The region is thus key to ventilation of the deep ocean [Orsi et al., 2002] and globally significant in driving changes in the carbon cycle and long-term climate fluctuations [Anderson et al., 2009; Marinov et al., 2006; Watson and Naveira Garabato, 2006]. 


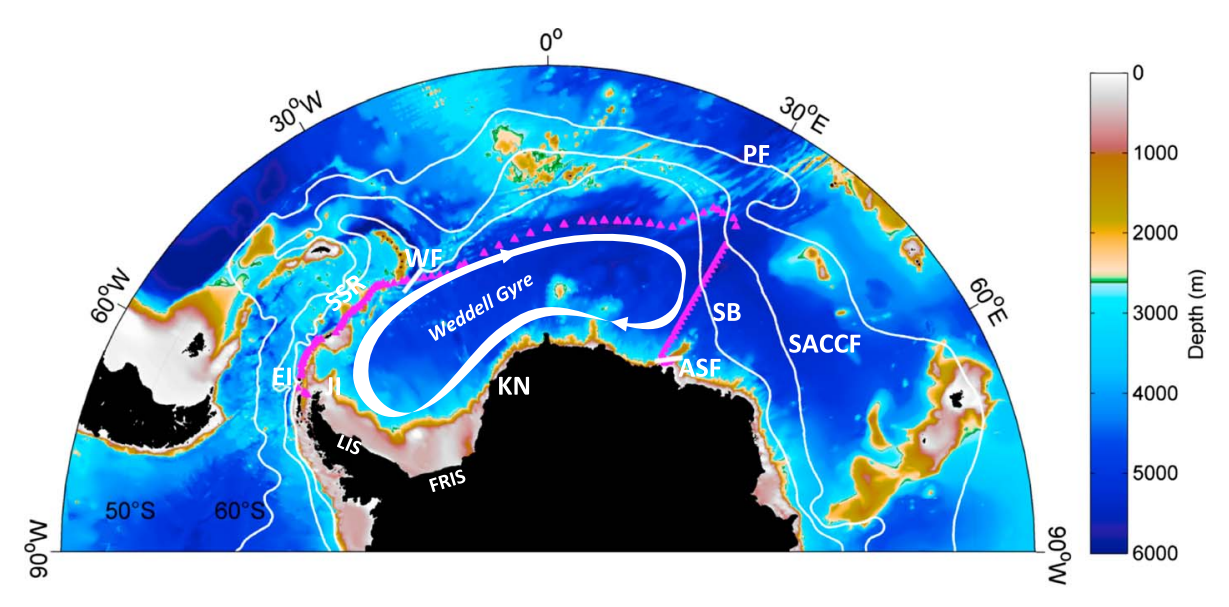

Figure 1. Station locations with respect to local geography, bathymetry, and positions of climatological fronts [Orsi et al., 1995]. Abbreviations: ASF = Antarctic Slope Front, EI = Elephant Island, FRIS = Filchner Ronne Ice Shelf, JI = Joinville Island, KN = Kapp Norvegia, LIS = Larsen Ice Shelf, PF = Polar Front, SACCF = Southern Antarctic Circumpolar Current Front, SB = Southern Boundary, SSR = South Scotia Ridge, and WF = Weddell Front. Bathymetry is from ETOPOv2 [U.S. Department Commerce, 2006].

The Weddell Gyre is one of the key regions of the Southern Ocean for the formation of deep and bottom waters [Orsi et al., 1999], in the form of Weddell Sea Deep Water (WSDW) and Weddell Sea Bottom Water (WSBW), and is a primary conduit for injection of recently ventilated surface waters to the global abyss. Heat loss and brine rejection through sea ice production and basal ice shelf melting in the western and southern parts of the gyre [Nicholls et al., 2009] lead to the production of cold, dense shelf waters, which subsequently cascade down the continental slope to great depths. However, a lack of consensus regarding production rates currently exists [e.g., Jullion et al., 2014; Lumpkin and Speer, 2007; Orsi et al., 2002; Schodlok et al., 2002; Wang et al., 2009], leading to uncertainty in the estimates of deep ocean ventilation in the region. Similarly, there are divergent estimates for total (natural plus anthropogenic) carbon uptake from the atmosphere [Lenton et al., 2013] and storage within the water column [Khatiwala et al., 2013; Vázquez-Rodríguez et al., 2009], resulting from differences in methodology used (e.g., atmospheric inversion, ocean biogeochemical model, ocean inversion, and sea-surface observations) and data availability. While the seasonal cycle is the dominant factor in the Southern Ocean air-sea carbon dioxide $\left(\mathrm{CO}_{2}\right)$ flux variability, its variation interannually and on smaller regional scales is not well constrained. Uptake is driven by biological drawdown, itself a result of increased light availability and stratification in the ice-free summer months, whereas outgassing dominates in winter following entrainment of DIC-rich waters through mixed layer deepening [Lenton et al., 2013; Metzl et al., 2006; Takahashi et al., 2009]. Equally, assessments of long-term trends are limited by poor data coverage [Lenton et al., 2013] except for a number of limited locations [Huhn et al., 2013; van Heuven et al., 2011].

In this work we establish a total carbon budget for the entire Weddell Gyre region (see Figure 1), extending from the Antarctic Peninsula eastward to $30^{\circ} \mathrm{E}$ and assess the air-sea $\mathrm{CO}_{2}$ flux variability of the region. Measurements of total DIC from three full-depth hydrographic sections completely encircling the gyre are combined with velocity fields derived from a box inversion to integrate carbon fluxes into and out of the region, in both the ocean interior and through the air-sea interface. Sea surface fugacity of carbon dioxide $\left(f \mathrm{CO}_{2}\right)$ observations are then used to investigate the seasonal cycle and annual mean sink/source state and to compare with inversion-derived outputs. Finally, a third independent estimate of the residual air-sea $\mathrm{CO}_{2}$ flux for the region is estimated from the differences in winter and summer biogeochemical characteristics at the surface.

\section{Data}

Three hydrographic cruises were conducted in 2008-2010 around the Weddell Gyre (Figure 1). The U.S. Climate Variability and Predictability (CLIVAR) cruise I6S (Expocode 33RR20080204, 4 February to 17 March 2008) was a quasi-meridional reoccupation of the $30^{\circ} \mathrm{E}$ section between South Africa and Antarctica on the R/V Roger Revelle [Speer and Dittmar, 2008]. DIC measurements were made by coulometry [Wanninkhof et al., 2009] using two analytical systems based on a Single Operator Multiparameter Metabolic Analyzer 


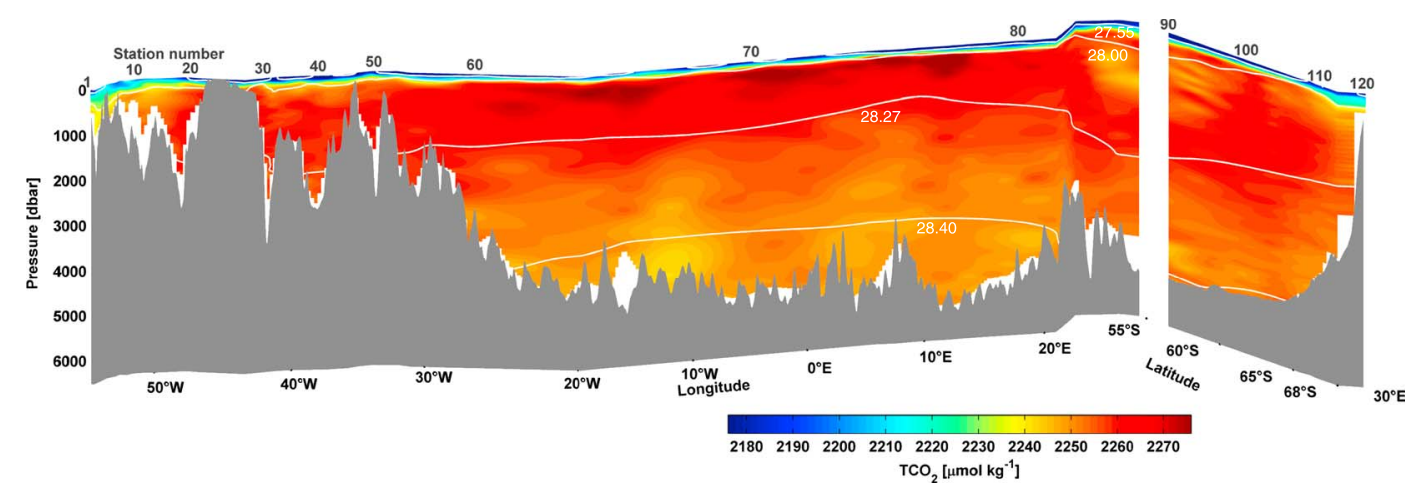

Figure 2. Total dissolved inorganic carbon field in $\mu \mathrm{mol} \mathrm{kg}^{-1}$ for the three hydrographic cruises encircling the Weddell Gyre (northward view). Station numbers are shown above the sea surface. Neutral density contours indicate separation of major water masses: SW $\left(\gamma_{n}<27.55\right)$, WW (27.55 $\left.<\gamma_{n}<28.0\right)$, WDW $\left(28.0<\gamma_{n}<28.27\right)$, WSDW $\left(28.27<\gamma_{n}<28.40\right)$, and WSBW $\left(\gamma_{n}>28.40\right)$.

[Johnson et al., 1999] and calibrated using certified reference materials (CRMs), Batch 85 [Dickson et al., 2003]. Analytical accuracy and precision were calculated to be $1.1 \mu \mathrm{mol} \mathrm{kg}{ }^{-1}$. Two UK Antarctic Deep Water Rates of Export (ANDREX) cruises completed the enclosure of the gyre, following its northern edge from $30^{\circ} \mathrm{E}$ to the Antarctic Peninsula: JC30 on the RRS James Cook (26 December 2008 to 30 January 2009) from $30^{\circ} \mathrm{E}$ to $17^{\circ} \mathrm{W}$ (Expocode $740 \mathrm{H} 20081226$ ) [Bacon and Jullion, 2009] and cruise JR239 on the RRS James Clark Ross (19 March to 24 April 2010) from $57^{\circ} \mathrm{W}$ to $17^{\circ} \mathrm{W}$ (Expocode 74JC20100319) [Meredith, 2010]. On both cruises, DIC was measured by coulometry using two instruments (Versatile INstrument for the Determination of Total inorganic carbon and titration Alkalinity 3C, MARIANDA, Germany [Mintrop, 2004]) and calibrated using CRMs. For JC30, Batch 92 was used, achieving an accuracy of $2.0 \mu \mathrm{mol} \mathrm{kg}{ }^{-1}$ and a precision of $1.6 \mu \mathrm{mol} \mathrm{kg}^{-1}$. For JR239, Batches 90,96 , and 97 were used, achieving an accuracy of $2.9 \mu \mathrm{mol} \mathrm{kg}{ }^{-1}$ and a precision of $2.0 \mu \mathrm{mol} \mathrm{kg}{ }^{-1}$. All three cruises occurred outside the window for inclusion in the CARbon dioxide IN the Atlantic Ocean (CARINA) hydrographic data intercomparison exercise [Key et al., 2010]. Therefore, all DIC, alkalinity, oxygen, nutrients, and salinity measurements were independently checked for systematic biases following CARINA procedures [Key et al., 2010; Tanhua et al., 2010], using data from an additional 59 historical, regional cruises for comparison. Biases were identified, and multiplicative adjustments were applied to some oxygen $\left(\mathrm{O}_{2}\right)$ and nutrient data sets, for data consistency $(740 \mathrm{H} 20081226$, stations $69-89 \mathrm{O}_{2}: 1.02$, Silicate: $0.98 ; 74 \mathrm{JC} 20100319$, stations $1-68 \mathrm{O}_{2}: 1.03$, Silicate: 1.02 , Phosphate: 1.03 ). No further adjustments were identified as necessary according to CARINA methodology for any other data sets (i.e., biases did not exceed $\pm 4 \mu \mathrm{mol} \mathrm{kg}^{-1}$ for DIC, $\pm 6 \mu \mathrm{mol} \mathrm{kg}^{-1}$ for alkalinity, $\pm 1 \%$ for oxygen, $\pm 2 \%$ for nutrients, and \pm 0.005 for salinity). All cruise data are available from the CLIVAR and Carbon Hydrographic Data Office (http://cchdo.ucsd.edu/).

\subsection{Oceanographic Setting}

The full-depth distribution of DIC around the Weddell Gyre is shown in Figure 2. The ACC is a key influence in the region, and its eastward flow is concentrated along a number of fronts. The cruise track crosses the most southerly of these-the Southern ACC front (SACCF) and Southern Boundary (SB) of the ACC - at its northeastern corner (Figure 1). The SB marks the most poleward extent of Circumpolar Deep Water (CDW) at this longitude [Orsi et al., 1995]. With no direct ventilation source, this water mass enters the Weddell Gyre from the ACC at its eastern edge and acts as a salinity source for all other water masses poleward of the Southern Boundary. Upon entering the Weddell Gyre, CDW characteristics are modified greatly by mixing, and it is commonly known as Warm Deep Water (WDW, $28<$ neutral density, $\gamma_{n}<28.27$ ) because it is the warmest of the subsurface water masses [Orsi et al., 2002]. Compared to incoming CDW, WDW exhibits increased concentrations of DIC and reduced oxygen concentrations in the interior gyre, indicative of the accumulating effect of remineralization of sinking particulate organic matter [Hoppema et al., 2002]. Surface waters $\left(S W, \gamma_{n}<27.55\right)$ are typified by lower DIC values caused by enhanced biological and solubility pumps where increased productivity and warmer summer temperatures lead to reduced inorganic carbon

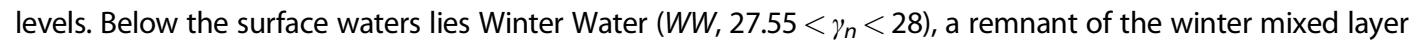


that is eroded by the upwelling of warmer, more saline WDW. The majority of the water column in the Weddell Gyre consists of WSDW $\left(28.27<\gamma_{n}<28.40\right)$ and WSBW $\left(\gamma_{n}>28.40\right)$, which collectively contribute to the $A A B W$ that occupies the lower limb of the overturning circulation in the Atlantic Ocean. These deep waters are formed through the densification of shelf waters by sub-ice-shelf processes and intense air-sea interaction prior to mixing with WDW [Foldvik et al., 1985; Foster and Carmack, 1976], and the impact of DIC-poor shelf waters on their formation in the Weddell Gyre causes DIC concentrations to decrease to $\sim 2240 \mu \mathrm{mol} \mathrm{kg}^{-1}$ toward the bottom. While both contributors to $A A B W$ follow the gyre circulation, only WSDW is able to cross the South Scotia Ridge (SSR) and spread northward directly [Naveira Garabato et al., 2002] carrying a significant carbon loading [Ríos et al., 2012], while WSBW is topographically constrained within the Weddell Basin and must upwell into the WSDW class before escaping northward. The major export location from the gyre is focused at the Weddell Front (WF) at $\sim 22^{\circ} \mathrm{W}$ (see Figure 1), which marks the separation of warmer CDW to the north from colder WDW to the south, while a substantial import from the east of $A A B W$ formed outside of the gyre occurs at the Antarctic Slope Front (ASF) at $30^{\circ} \mathrm{E}$, with a DIC signature similar, but slightly smaller [Hoppema et al., 2001], to that for Weddell Sea varieties.

\section{Methods}

\subsection{Box Inverse Model}

The total contemporary carbon budget for the Weddell Gyre is computed by the combination of the DIC field with an estimate of the underlying circulation (horizontal geostrophic and diapycnal velocities, eddy fluxes, the air-sea exchange of heat and freshwater, and freshwater transport through solid sea ice export), diagnosed by means of a box inverse model, computed by Jullion et al. [2014], and summarized here. Conservation of mass, heat, and salt is imposed within the region enclosed by the three sections described in the text complemented by temperature and salinity from the 2005 SR04 section between Joinville Island (near the Antarctic Peninsula) and Kapp Norvegia, $\sim 8^{\circ} \mathrm{W}, \sim 70^{\circ} \mathrm{S}$ (cruise ANT XXII/3 [Fahrbach, 2006]) on the Antarctic coast. The additional SR04 section is used to minimize the influence of shelf-slope processes in the vicinity of the ice shelves in the south and west of the gyre on the transport solution. An additional constraint on the transport of the ACC between stations 82 and $111(0 \pm 5$ sverdrup (Sv)) is also imposed to aid in improving the solution. The sections are divided vertically into 10 layers separated by neutral density interfaces [Jackett and McDougall, 1997]. The layer interfaces are selected to correspond with the boundaries of the major water masses in the region. The ocean surface is considered to be permeable to exchanges of heat and freshwater between the ocean and the overlying atmosphere or ice. The inverse model seeks to apply the minimum amount of correction (in a least squares sense) to the observation-based estimate of the regional circulation across the sections in order to satisfy the conservation constraints. Volume transport estimates derived by Jullion et al. [2014] can thus be combined with DIC observations interpolated on to the same spatial grid to obtain carbon transport fields.

Uncertainties are derived by the application of a Monte Carlo simulation, where 2000 runs of the inversion were conducted applying a normally distributed offset for barotropic velocity and associated unknowns, with the mean of these perturbations being equal to the inverse output, and its standard deviation equal to the final model error. The error estimates presented here also include the contribution of DIC measurement uncertainties $\left( \pm 2-3 \mu \mathrm{mol} \mathrm{kg}^{-1}\right)$, which were also applied during the Monte Carlo simulation in the same manner as uncertainties for the velocities. The transport uncertainties represent the cumulative effect of short-term barotropic perturbations on the final circulation field.

The nonsynoptic nature of the input data (taken from 2005 to 2010) is not thought to affect the derived volume transports. The inverse model acts to minimize the influence on the solution of short-term barotropic anomalies by adjusting velocities; thus, the volume transport estimates are considered to be representative of a long-term (decadal) mean state. For chemical transports, however, while subsurface estimates can be thought to be typical of a multiyear average, a similar description for the surface layer is not possible. The large seasonal variability of carbon levels in these waters presupposes that the estimated carbon transport may simply be representative of a long-term summer signal.

\subsection{Air-Sea $\mathrm{CO}_{2}$ Fluxes}

Historical surface ocean measurements of $\mathrm{fCO}_{2}$ are used in a two-step neural network approach to build monthly air-sea $\mathrm{CO}_{2}$ flux maps for the Weddell region for the period of 1998-2011. This approach allows 
the assessment of both interannual and seasonal variabilities in sea surface fluxes independent of the hydrographic section measurements.

Following the neural network method of Landschützer et al. [2014a], distinct biogeochemical provinces are defined according to shared independent predictor variable- $-p \mathrm{CO}_{2}$ relationships using a neural network clustering algorithm. A feed-forward network method is then applied in each province to derive unique, nonlinear $p \mathrm{CO}_{2}$-predictive equations for monthly and $1^{\circ} \times 1^{\circ} \mathrm{grid}$ resolution. Global data were used in order to overcome limited data coverage. The gridded observations of sea surface $\mathrm{fCO}_{2}$ from Surface Ocean $\mathrm{CO}_{2}$ Atlas (SOCAT) v2 [Bakker et al., 2014] are converted to $p \mathrm{CO}_{2}$ [e.g., see Körtzinger, 1999] using in situ temperature and mean monthly sea level atmospheric pressure of National Center for Environmental Prediction [Kalnay et al., 1996]. Predictor variables for network training were National Oceanic and Atmospheric Administration optimally interpolated surface temperature v2 [Reynolds et al., 2002], Globcolour-based chlorophyll a concentration (http://www.globcolour.info), sea surface salinity and ocean mixed layer depth (from the Estimating the Circulation and Climate of the Ocean project) [Menemenlis et al., 2008], and the monthly atmospheric $\mathrm{CO}_{2}$ mole fraction from GLOBALVIEW-CO2 [2011]. Predicted $p \mathrm{CO}_{2}$ values for each grid cell and month are then combined with monthly wind speed fields (from the cross-calibrated multiplatform product [Atlas et al., 2011]) to calculate the air-sea $\mathrm{CO}_{2}$ flux, using the gas transfer coefficient of Sweeney et al. [2007] and the quadratic wind speed dependence of the gas transfer velocity of Wanninkhof [1992]. As in the $p \mathrm{CO}_{2}$ climatology of Takahashi et al. [2009], the presence of sea ice is accounted for by making the flux proportional to the fraction of sea-ice-free water (derived from monthly sea ice fields of Rayner et al. [2003]).

Following the global analysis of Landschützer et al. [2014a], the uncertainty of the neural network-predicted monthly sea surface $p \mathrm{CO}_{2}$ fields specifically for the Weddell Gyre is tested by conducting a residual analysis on two separate observational data sets: SOCATv2 and additional data from the Global Ocean Surface Water Partial Pressure of $\mathrm{CO}_{2}$ Database (LDEOv2013) [Takahashi et al., 2014] that are not included in SOCATV2. While the former is not an independent validation (as the same data are used to generate $p \mathrm{CO}_{2}$ maps), the data can be used to identify systematic biases; the latter are, however, a truly independent source for comparison. A paucity of regional data both spatially and temporally limits the analysis to an annual basis across the 1998-2011 time frame. The mean annual bias (observational data-neural network estimates) \pm root-mean-square deviation is computed as $-4.0 \pm 15.4 \mu \mathrm{atm}$ for SOCATv2 and $-3.4 \pm 16.8 \mu \mathrm{atm}$ for LDEOv2013 and represents both spatial and temporal variabilities. There is no discernible residual trend for either data set across the time period, although there is better agreement (lower residuals) in years with more observations. Hence, annual biases are generally larger in data sparse years, particularly compared to the independent data product. This is also reflected in our fairly large uncertainty estimate (see below). The residual analysis thus finds a small bias and residual spread for both dependent and independent observations that are similar to those obtained for the global analysis ( $1.5 \pm 26 \mu \mathrm{atm}$ ) [Landschützer et al., 2014a]. Following the same procedure, an assessment of the uncertainty in the air-sea flux estimates was undertaken for the Weddell Gyre. Combining the error associated with $p \mathrm{CO}_{2}$ gridding described above with that associated with the calculation of the gas transfer velocity (the standard deviation of results from four different commonly used gas transfer formulations) enables the quantification of the error associated with the Weddell Gyre's $\mathrm{CO}_{2}$ source and sink terms.

\subsection{Surface Carbon Balance}

Biological production, salinity changes, and DIC-rich deepwater entrainment are each major processes influencing $\mathrm{CO}_{2}$ content in surface waters. By quantifying their individual contributions to the surface carbon balance, we can reach a third independent estimate of the annual mean air-sea $\mathrm{CO}_{2}$ flux. The approach of Hoppema et al. [1999] is applied in this instance, utilizing differences in oxygen, salinity, and nutrient concentrations in summer and winter in surface and WDW source waters to infer contributions to net changes in DIC. The WDW entrainment rate is estimated by calculating the fraction of WDW, $f_{\mathrm{WDW}}$, necessary to change the surface layer concentration $[X]_{S L}$ of oxygen from the beginning of the entrainment period ([X] $]_{S L 1}$, the start of winter and increased sea ice coverage (stations 62-68, covered by sea ice approximately 4 weeks later in May)) to the end of the entrainment period $\left([X]_{S L 2}\right.$, retreat of sea ice at the start of summer (stations $72-78$, covered by sea ice $\sim 1$ week prior to sampling in early January)), according to equation (1):

$$
f_{\mathrm{WDW}}=\left([\mathrm{X}]_{\mathrm{SL} 1}-[\mathrm{X}]_{\mathrm{SL2}}\right) /\left([\mathrm{X}]_{\mathrm{WDW}}-[\mathrm{X}]_{\mathrm{SL} 2}\right)
$$




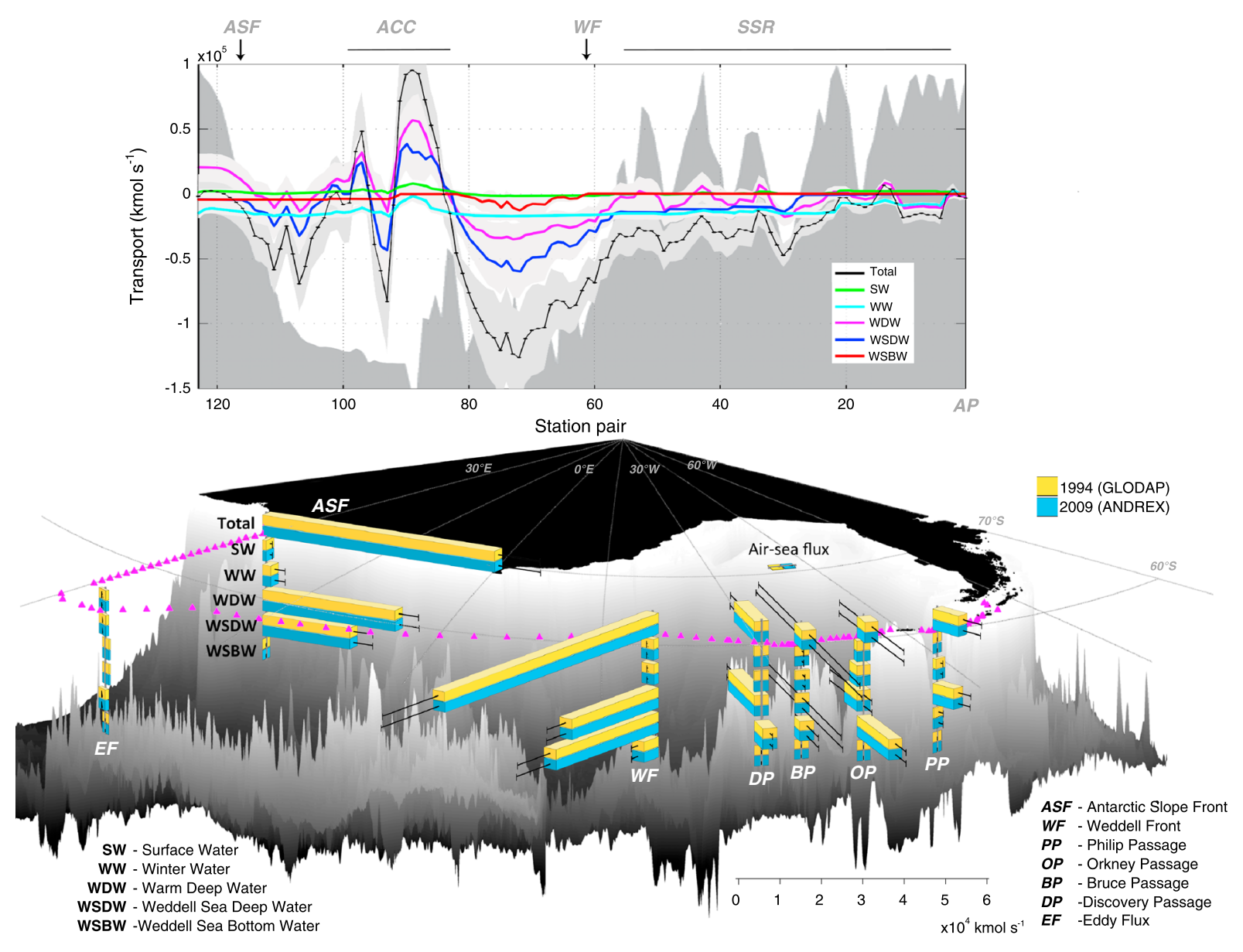

Figure 3. (a) Cumulative contemporary carbon transports (with shaded uncertainties) for a number of water mass classifications. The positive (negative) values indicate the transports into (out of) the Weddell Gyre box. Abbreviations: WF = Weddell Front, ACC = Antarctic Circumpolar Current, ASF = Antarctic Slope Front, $\mathrm{AP}=$ Antarctic Peninsula, and SSR = South Scotia Ridge. (b) Air-sea carbon flux and total carbon transports for ANDREX and GLODAP data inputs for the full water column and separated into constituent water masses for main import/export regions of the gyre, namely, the deep passages of the South Scotia Ridge and the Weddell Front and Antarctic Slope Front (southward view). The error bars indicate the transport uncertainties (standard deviation) to represent short-term variability of flows. Bathymetry from the ETOPO $22 \mathrm{~min}$ global bathymetry database.

where $[X]_{\text {WDW }}$ is the concentration in Warm Deep Water. Oxygen is chosen to trace this process as temperature and salinity are nonconservative in the upper ocean due to heat exchange with the atmosphere and sea ice formation/ice melt, respectively. The method assumes negligible changes in the oxygen concentration by air-sea interaction (due to sea ice coverage) and biological activity under sea ice (due to wintertime darkness). Using the entrainment rate, substitution of DIC concentrations in equation (1) yields the annual increase in surface layer carbon levels due to entrainment.

Between sea ice retreat and sea ice formation at the onset of the following winter, the surface layer is freshened through the action of precipitation and glacial melt, both reducing the DIC concentration. Quantification of this process is achieved by the use of the salinity difference between the two periods; normalizing prewinter DIC concentrations for this salinity change and comparing to its presummer value reveal the overall effect of the freshwater addition.

Biological production moves the air-sea $\mathrm{CO}_{2}$ disequilibrium in the opposite sense to WDW entrainment by reducing inorganic nutrient and carbon concentrations through photosynthesis. Part of the organic material produced is subsequently exported from the surface layer to greater depths through various processes prior to remineralization (the "biological carbon pump"). Assuming surface waters derive solely from WDW, it is possible to quantify this process by comparing biologically modified parameters in surface water and WDW at the end of the productive period (the onset of winter). Changes in oxygen or carbon dioxide are not 
Table 1. Summary of Total Dissolved Inorganic Carbon Transports Across the Boundary Encircling the Weddell Gyre, for Full-Depth and Specific Water Mass Types Based on the ANDREX and GLODAP Data Sets ${ }^{a}$

\begin{tabular}{lccc} 
& $\begin{array}{c}\text { Carbon Budget ANDREX } \\
(\sim 2009)\left(\mathrm{PgC}^{-1}\right)\end{array}$ & $\begin{array}{c}\text { Carbon Budget GLODAP } \\
(\sim 1994)\left(\mathrm{PgC} \mathrm{yr}^{-1}\right)\end{array}$ & Volume Transports (Sv) \\
\hline SW $\left(\gamma_{n}<27.55\right)$ & $0.837 \pm 0.031$ & $0.818 \pm 0.032$ & $1.0 \pm 0.6$ \\
WW $\left(27.55<\gamma_{n}<28\right)$ & $-4.971 \pm 0.084$ & $-4.959 \pm 0.084$ & $-5.7 \pm 1.7$ \\
WDW $\left(28<\gamma_{n}<28.27\right)$ & $8.060 \pm 0.153$ & $8.045 \pm 0.152$ & $9.1 \pm 3.0$ \\
WSDW $\left(28.27<\gamma_{n}<28.40\right)$ & $-2.065 \pm 0.117$ & $-2.038 \pm 0.116$ & $-2.3 \pm 2.3$ \\
WSBW $\left(28.40<\gamma_{n}\right)$ & $-1.623 \pm 0.081$ & $-1.615 \pm 0.081$ & $-1.8 \pm 1.6$ \\
Volume total & $0.239 \pm 0.009$ & $0.252 \pm 0.009$ & $0.3 \pm 0.2$ \\
Eddy flux & $-0.290 \pm 0.004$ & $-0.289 \pm 0.004$ & $-0.4 \pm 0.0$ \\
Sea-ice export & $-0.001 \pm 0.0007$ & $-0.001 \pm 0.0007$ & $-0.013 \pm 0.002$ \\
Total storage & $-0.005 \pm 0.001$ & $-0.005 \pm 0.001$ & \\
Residual & $0.058 \pm 0.010$ & $0.044 \pm 0.010$ & \\
(Air to sea flux) & & & \\
\hline
\end{tabular}

${ }^{a}$ Positive is the flux into the region; negative is the flux out of the region. Uncertainties represent the $95 \%$ confidence intervals. Water mass transports are from Jullion et al. [2014]. SW: Surface Water, WW: Winter Water, WDW: Warm Deep Water, WSDW: Weddell Sea Deep Water, and WSBW: Weddell Sea Bottom Water.

suitable to track surface production due to the influence of air-sea exchange on their levels. However, nutrients are more useful as they do not (phosphate) or negligibly (nitrate, through denitrification and $\mathrm{N}_{2}$ fixation) interact with the atmosphere. Mean nutrient and DIC concentrations are determined for the surface and WDW layers for winter-onset conditions using data from April 2010, from the latest stations of the JR239 section (stations 62-68, where there was an approximately 4 week gap before complete coverage by sea ice in mid-May [Nolin et al., 1998]), and nutrient consumption rates are calculated for them. Through the use of stoichiometric ratios, the analogous effect on carbon levels and the strength of the biological carbon pump can be estimated. All values are salinity normalized following the convention of $[X]^{\text {SalNorm }}=([X \cdot 35]) / S a l$ in order to remove the effects of freshwater processes (precipitation and glacial melt) on surface water concentrations.

\section{Results}

\subsection{Box Inverse Model}

Cumulative transports of contemporary carbon for both full-depth and individual water masses along the length of the Weddell Gyre box are shown with accompanying uncertainties in Figure 3a and Table 1, where positive (negative) values indicate net import (export). A number of features dominate the plot: large carbon import and export signals are associated with the SACCF and Southern Boundary of the ACC, where the ACC traverses the domain's northeastern corner (stations 80-95), but their net effects on total box transports are negligible due to the imposition of a net zero volume transport constraint. To the west, major full-depth outflow around station 62 is associated with the Weddell Front. From station pair 75, there is evidence of the inner gyre recirculation [Jullion et al., 2014], while waters from the Indian Ocean sector of the Southern Ocean [Hoppema et al., 2001; Meredith et al., 2000] enter the box at the eastern boundary (around station 113) at the Antarctic Slope Front. Of the individual water masses, WDW and WSDW contribute most to the overall transports. WSDW transport across the section mainly takes place at locations where its movement is not restricted by topography, i.e., east of the SSR and lower parts of the continental slope, although some flow occurs through the deep passages of the SSR (notably Orkney Passage; station 33). The densest waters of WSBW are for the most part constrained to the Weddell region by bathymetry, with only a meandering signal across the cruise track east of the SSR between stations 63 and 80 and a small net export into the ACC at station 93.

At the SSR, transport is mainly through the deep passages. As demonstrated most clearly by the WDW layer, flow through these gaps is bidirectional with northward exports being intensified on their western side and southward imports intensified on their eastern side. Lighter waters of the $S W$ and $W W$ have the smallest total transports, with those in the ACC dominating the overall signal. A sizable WW export occurs at approximately station 5 to the east of Elephant Island, is associated with the disintegration of the ASF over the South Scotia Ridge, and has a large effect on the net budget for WW. Given that the DIC measurement uncertainty is approximately $0.1 \%$ of the mean DIC concentration, carbon transport uncertainties scale in size with volume transport magnitudes, such that the velocity estimate is by far the largest contributor to the overall error. 


\subsection{Weddell Gyre Contemporary Carbon Budget}

The combination of the measured DIC field with an estimate of the underlying circulation yields a total net oceanic carbon transport into or out of the Weddell Gyre (Table 1). However, to construct a budget for the region, it is necessary to include other processes that add or remove carbon from the local system: the contributions of eddy fluxes, sea ice export, glacial/freshwater inputs, carbonate sedimentation, and accumulation of anthropogenic carbon in the water column are thus additionally calculated. Sensitivity of the budget to the synoptic nature of the ANDREX DIC measurements is also tested through the use of gridded DIC outputs from the Global Data Analysis Project (GLODAP) carbon synthesis project [Key et al., 2004], a data set that collates high-quality, internally consistent hydrographic data principally from World Ocean Circulation Experiment (WOCE) cruises of the 1990s. GLODAP DIC concentrations are interpolated onto ANDREX bottle locations before combination with ANDREX hydrographic data-derived volume transport estimates. Like ANDREX, GLODAP cruise timings are summer dominated but act as a marker of a decadally different DIC signal, temporally separated from the ANDREX data by approximately 15 years. The Southern Ocean State Estimate model [Mazloff et al., 2010] is used to derive eddy flux contributions for each of the 10 model neutral density layers [Jullion et al., 2014]. Earlier inverse models have either classified eddy fluxes as a source of uncertainty or disregarded them completely. In this study, it was anticipated that eddy-induced transports would constitute a sufficiently significant contribution to exchanges across the rim of the gyre [Schröder and Fahrbach, 1999] to necessitate their quantification. Here they balance the inversion-derived net horizontal transport divergence [Jullion et al., 2014] and although relatively small volumetrically, carry a significant carbon signal. The mean DIC concentrations for each layer (weighted to account for changing station frequency resolution) are combined with the advective and diffusive eddy terms for each layer, yielding a net export by eddy fluxes of $-0.290 \pm 0.004 \mathrm{Pg} \mathrm{Cyr}^{-1}$. Carbon associated with sea ice export is estimated using the inversion-derived solid freshwater flux of $13 \pm 1 \mathrm{~m} \mathrm{~Sv}$ across the edge of the gyre and a mean sea ice DIC concentration of $\sim 300 \mu \mathrm{mol} \mathrm{kg}^{-1}$ measured in the Amundsen Sea [Fransson et al., 2011]. This results in a loss of carbon from the region due to sea ice export of $-0.00142 \pm 7 \mathrm{e}^{-5} \mathrm{PgC} \mathrm{yr}^{-1}$. The loss of carbon through burial is deemed negligible due to substantial remineralization in the upper water column [Usbeck et al., 2002; Wefer and Fischer, 1991] and low overall regional burial rates [Hulth et al., 1997; Sayles et al., 2001]. It is not possible to estimate the contribution of dissolved organic carbon to the overall budget due to the lack of associated measurements. Net water column carbon storage (corresponding to anthropogenic carbon buildup) is calculated using linear time trends in DIC concentrations estimated for individual density layers in the central Weddell Sea [van Heuven et al., 2011]. DIC increase rates are combined with water mass volumes derived from area and mean thicknesses extracted from the WOCE Global Hydrographic Climatology [Gouretski and Koltermann, 2004] for individual density layers to give a mean annual total storage term for the Weddell

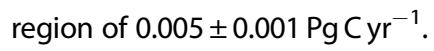

The combination of all import and export terms closes the carbon budget for the region, with the residual equivalent to the net annual air-sea flux term. Table 1 summarizes the ANDREX and GLODAP data-derived carbon budgets for the Weddell region, including the net contributions of individual water masses where a positive (negative) sign implies flux into (out of) the box. The uncertainties for all the budget terms are the $95 \%$ confidence intervals of the mean and are representative of a multi-annual-mean view of the carbon cycle in the Weddell Gyre for the 2005-2010 summer period.

Net oceanic carbon imports of $+0.239 \pm 0.009 \mathrm{Pg} \mathrm{Cyr}^{-1}$ for ANDREX and $+0.252 \pm 0.009 \mathrm{Pg} \mathrm{Cyr}^{-1}$ for GLODAP lead to net air-to-sea fluxes (oceanic uptake) of $0.058 \pm 0.010 \mathrm{Pg} \mathrm{Cyr}^{-1}$ and $0.044 \pm 0.010 \mathrm{PgC}^{-1}$, respectively. This implies that the Weddell Gyre region is $\mathrm{C} \mathrm{CO}_{2}$ sink and that the calculated flux for the 1990s is consistent with the late 2000s. The net oceanic term is principally dictated by deepwater transports, in particular the balance between the import of WDW and export of WW and $A A B W$ (as WSDW and WSBW) in the double-cell structure of the overturning circulation [Jullion et al., 2014]. Although uncertainties on these individual transports are relatively large, volume conservation imposed by the box inversion dictates that large imports will always be balanced by large exports and thus volume and carbon transport residual uncertainties are small. The net oceanic term is offset by sizable carbon export by the eddy volume flux that although volumetrically small $(-0.34 \pm 0.07 \mathrm{~Sv})$, balances the net horizontal transport divergence derived from the inversion [Jullion et al., 2014] and thus has an associated carbon signal of similar magnitude. Figure $3 \mathrm{~b}$ summarizes the total carbon budget, focusing on the major transports into and out of the region, and the decomposition of these into water mass contributions. The Antarctic Slope Front and the Weddell Front 

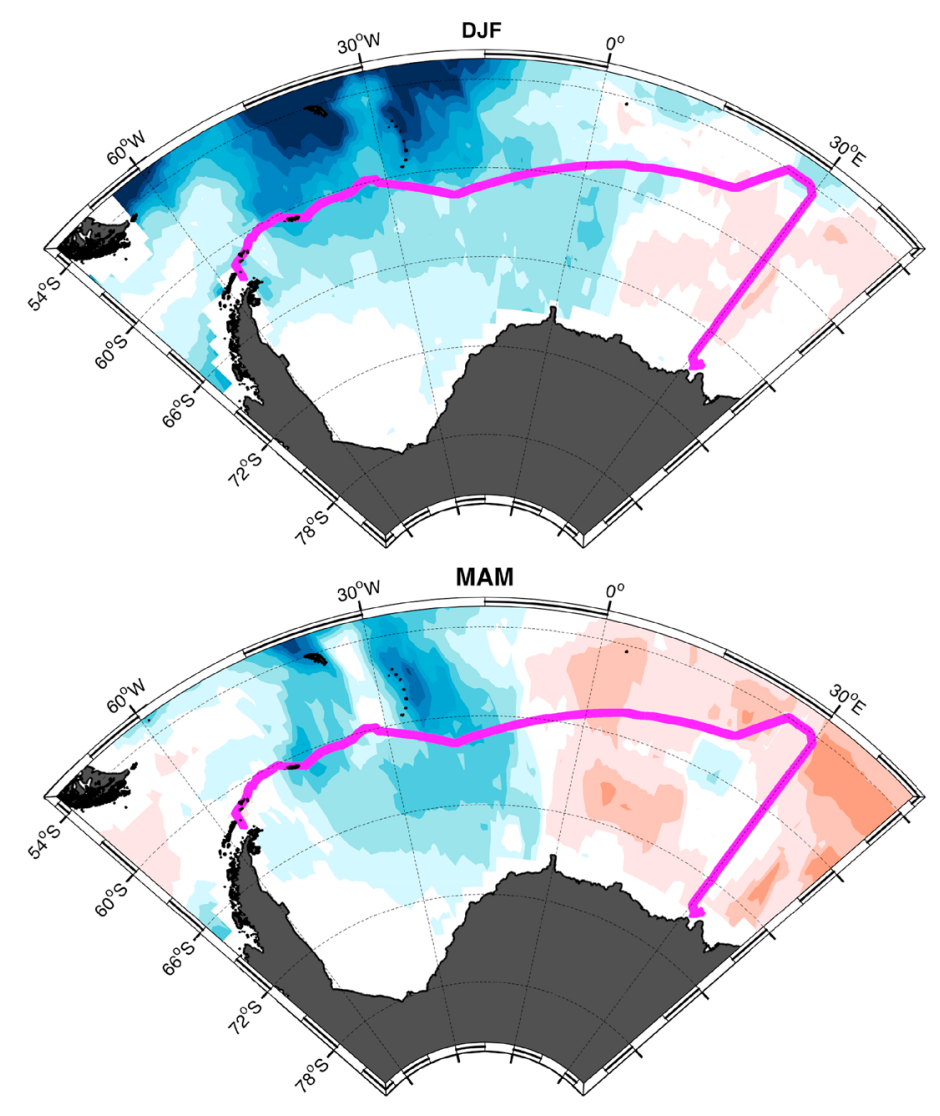

$\mathrm{TgC} / \mathrm{yr}$
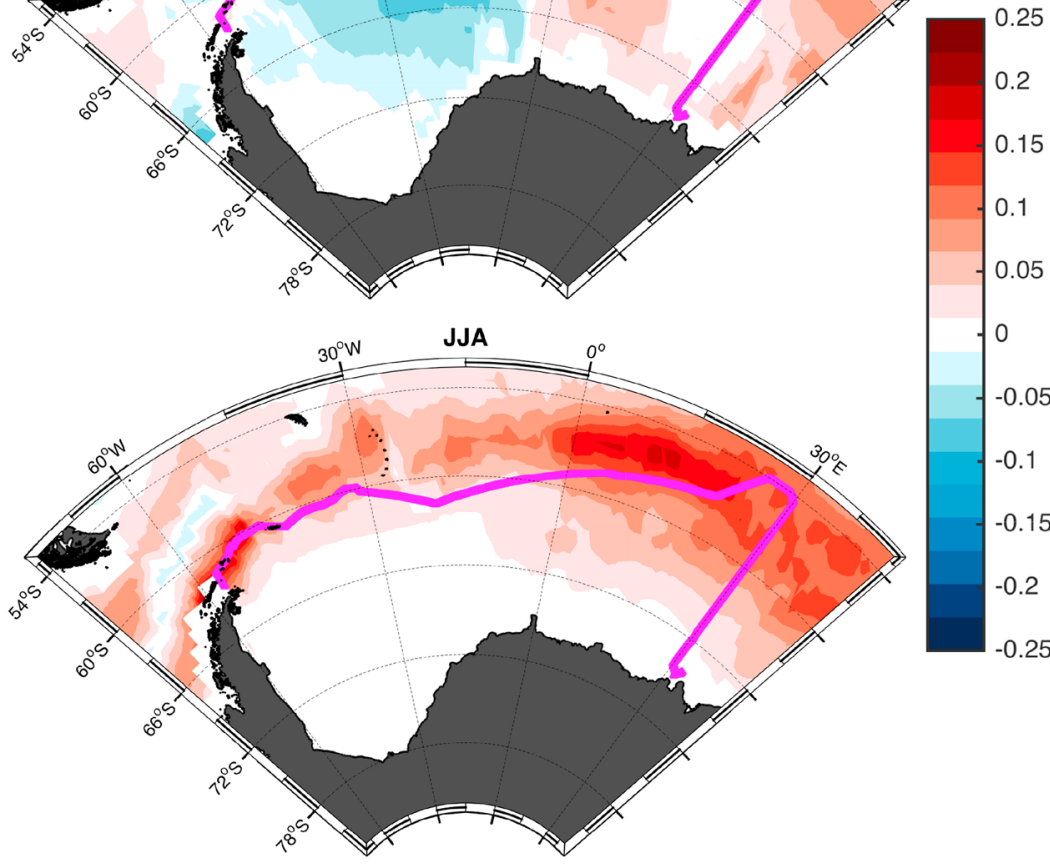

0.1

$-0.05$

0

$-0.05$

$-0.1$

$-0.15$

$-0.2$

$-0.25$

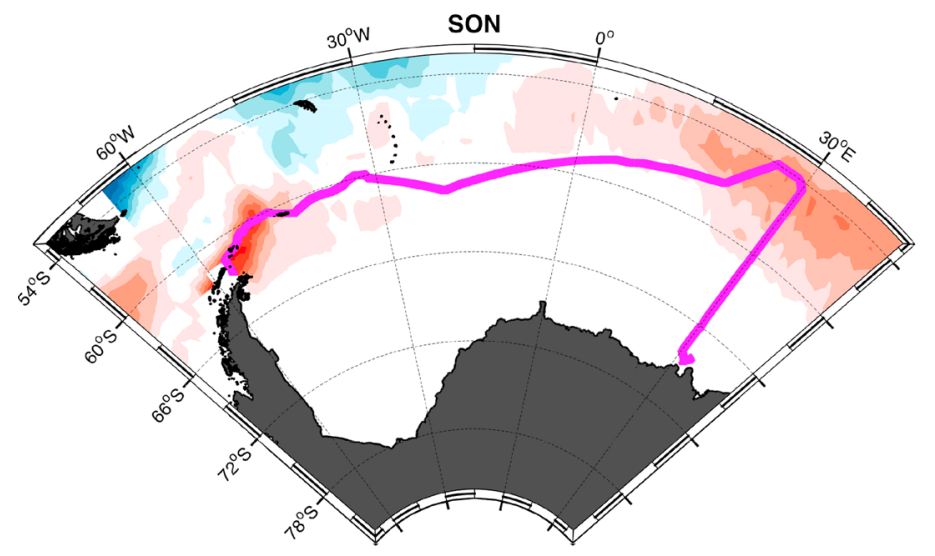

Figure 4 
regions are the locations of greatest transport magnitude, dwarfing the residual net air-sea flux and eddy fluxes. The importance and relatively large uncertainties of carbon transports at these fronts imply that the net budget is sensitive to the long-term balance between these flows. The effect of regional overturning and densification of water masses can be seen by the assessment of the WDW/AABW (WSDW + WSBW) relationship in these two counterbalancing transports as they pass through the region: WDW has a greater magnitude in imported flows, which then shifts to denser $A A B W$ waters dominating the exported flows. The substantial transports through the SSR identified in Figure $3 a$ are also visible here. The complex dynamics of movement through the passages is clear, with bidirectional flows of high variability throughout the water column, in addition to the large, sustained WSDW export through Orkney Passage [Naveira Garabato et al., 2002].

\subsection{Air-Sea $\mathrm{CO}_{2}$ Uptake}

Although small compared to oceanic transports, the box inverse-derived net air-to-sea flux is significantly different from zero for both carbon data sets and estimated to be 0.044 to $0.058 \pm 0.010 \mathrm{PgC} \mathrm{yr}^{-1}$. While there are some differences between ANDREX and GLODAP outputs, they are not statistically significant and indicate that the predominant control on the carbon fluxes is the underlying circulation rather than changes in carbon inputs over a 15 year period, despite an increase of $\sim 34 \mathrm{ppm} \mathrm{CO}_{2}$ in the atmosphere [Thoning et al., 2010]. The inverse model reduces the impact of time-varying transport processes (variable barotropic perturbations) on the final circulation field to the extent that it is thought to be representative of a multiyear to decadal mean state [Jullion et al., 2014]. However, the residual air-sea carbon uptake calculated may not be illustrative of the same time scale due to the temporally aliased nature of the input carbon data, whether collected during the summertime ANDREX or the summer-dominated GLODAP cruises. Independent neural network-derived monthly $\mathrm{CO}_{2}$ flux maps for the Weddell region between 1998 and 2011 are estimated to investigate seasonal variability and compare to the box inversion outputs.

Seasonal means for each $1^{\circ} \times 1^{\circ}$ grid cell using the entire 14 year neural network data set are shown in Figure 4, with positive values representing ocean to atmosphere outgassing and negative values indicating ocean uptake of $\mathrm{CO}_{2}$. During spring, maximum sea ice coverage (>95\% of box [Brown et al., 2014]) slowly recedes and the initial stages of biological production and sea ice melt start to drawdown carbon levels to the extent that the net outgassing signal begins to be supressed and reduced. Moving into summer, increased light availability, diminished sea ice coverage ( $<30 \%$ of box), greater stratification caused by ice melt and higher temperatures, and a possible ice melt fertilization effect lead to enhanced biological productivity [Bakker et al., 2008; Geibert et al., 2010], causing the drawdown of surface ocean $p \mathrm{CO}_{2}$ levels and a widespread net carbon uptake signal. The uptake continues into the autumn, albeit to a reduced extent: to the east, a slight net outgassing signal becomes visible, possibly as the balance between upwelling of high-DIC deep waters and biological uptake shifts more to the former. This area is known for its spatial and temporal variabilities [Bakker et al., 1997; Bellerby et al., 2004; Hoppema et al., 2000; Jabaud-Jan et al., 2004; Metzl et al., 1991; Robertson and Watson, 1995], and there is significant year-to-year variability in sign and magnitude of carbon flux across the 1998-2011 period for the area (Figure 5a), possibly related to changing wind fields and frontal positions. In winter, sea ice coverage reaches its greatest extent, with the deepening of the mixed layer bringing carbon-enriched waters to the surface and outgassing north of the ice edge. The largest flux signals are located north of the ANDREX region. These relate to the positions of the ACC fronts and the strong westerly winds driving deep upwelling and more northerly subduction. The fluxes greatly exceed those identified farther south, and the neural network approach reproduces well the regional source and sink trends across the Atlantic sector of the Southern Ocean observed with other methods [Gruber et al., 2009; Landschützer et al., 2014a; Lenton et al., 2013; Takahashi et al., 2009].

To investigate the interannual variability, the mean $1^{\circ} \times 1^{\circ}$ monthly air-sea $\mathrm{CO}_{2}$ flux estimates are determined for the Weddell region for the entire time series. Figure 5 a shows a recurrent seasonal signal of summer uptake and winter outgassing but also variability in flux magnitude on a year-to-year basis. For the earlier part

Figure 4. Mean seasonal air-sea $\mathrm{CO}_{2}$ fluxes for the Atlantic sector of the Southern Ocean calculated using 1998-2011 SOCATv2 [Bakker et al., 2014] sea-surface $\mathrm{fCO}_{2}$ measurements interpolated using a two-step neural network technique [Landschützer et al., 2013]. In common with most examinations of air-sea $\mathrm{CO}_{2}$ fluxes, negative fluxes indicate uptake of carbon by the ocean, and positive fluxes indicate ocean outgassing. The pink triangles indicate ANDREX station locations and the extent of the Weddell region. The white regions indicate zero air-sea flux, and within the Weddell box, represent the presence of sea ice. 

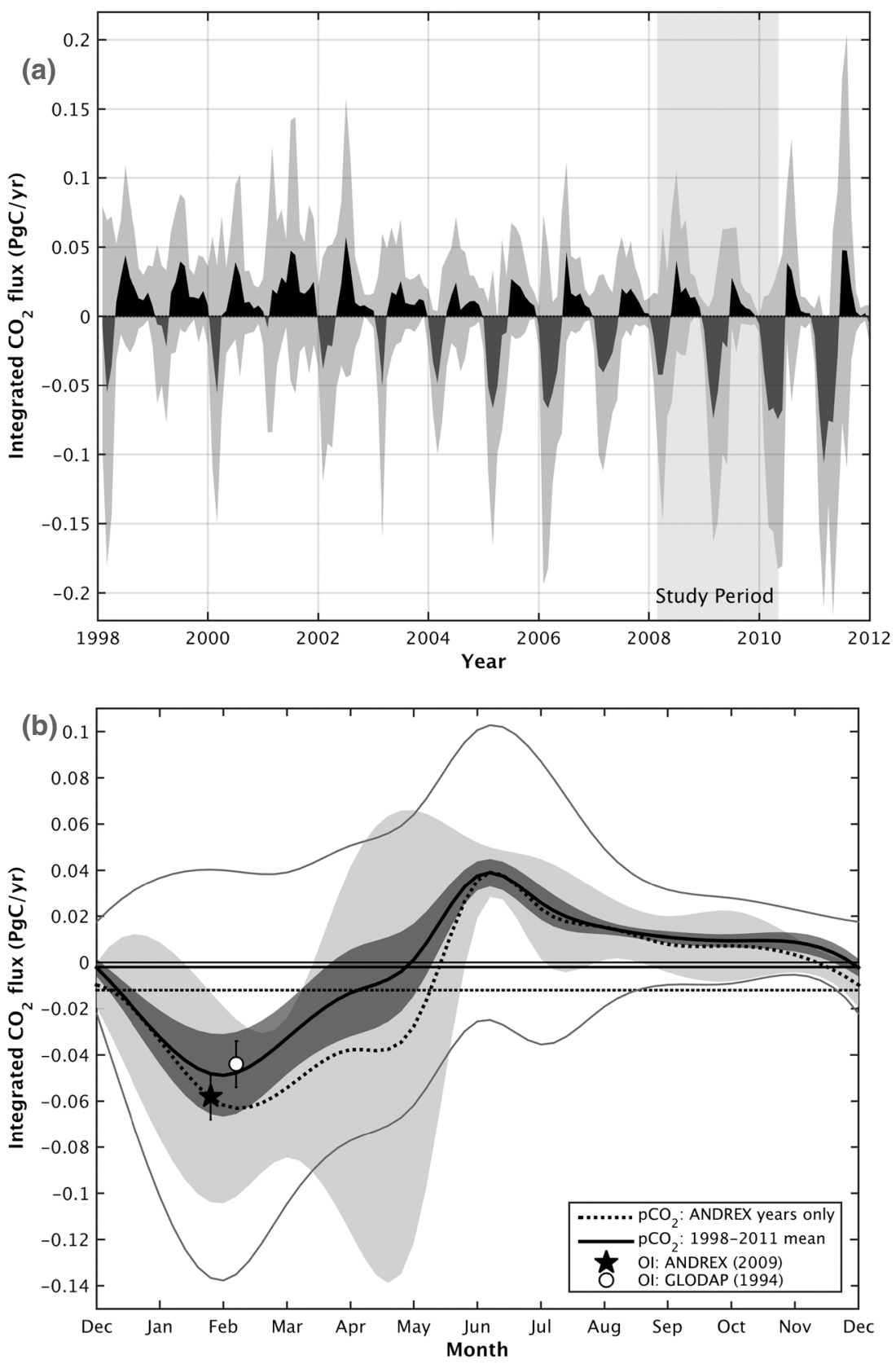

Figure 5. (a) Monthly air-sea $\mathrm{CO}_{2}$ fluxes for the Weddell region for 1998-2011. The light shaded area indicates the time period of hydrographic sections. The darker shaded area represents the best estimate of the uncertainty of these estimates, taking into account measurement, gridding, mapping, and air-sea flux uncertainties. (b) Mean monthly (curves) and annual (horizontal lines) air-sea $\mathrm{CO}_{2}$ fluxes for the Weddell region for 1998-2011 (solid line) and 2008-2010 (time span of hydrographic cruises) (dashed line). Summertime ocean inversion-derived estimates of air-sea $\mathrm{CO}_{2}$ fluxes for ANDREX and GLODAP input data sets are also shown. The shaded uncertainties represent the $95 \%$ confidence intervals of the variability of the data. The thin solid line curves represent the temporal and spatial variabilities in the fluxes, accounting for measurement, gridding, mapping, and air-sea flux uncertainties. Both Figures $5 \mathrm{a}$ and $5 \mathrm{~b}$ were calculated using SOCATv2 [Bakker et al., 2014] sea-surface $\mathrm{fCO}_{2}$ measurements interpolated using a two-step neural network technique [Landschützer et al., 2013]. In common with most examinations of air-sea $\mathrm{CO}_{2}$ fluxes, negative fluxes indicate uptake of carbon by the ocean, and positive fluxes indicate ocean outgassing. 
Table 2. Top: Mean Oxygen and DIC Concentrations for the Surface Mixed Layer and WDW Layer for April and January ${ }^{\mathrm{a}}$

\begin{tabular}{|c|c|c|c|c|c|}
\hline & & \multicolumn{2}{|c|}{ Surface Layer } & \multicolumn{2}{|c|}{ WDW Layer } \\
\hline & & $\begin{array}{l}\text { Winter Onset } \\
\text { (April) }\end{array}$ & $\begin{array}{c}\text { Summer Onset } \\
\text { (Jan) }\end{array}$ & $\begin{array}{l}\text { Winter Onset } \\
\text { (April) }\end{array}$ & $\begin{array}{c}\text { Summer Onset } \\
\text { (Jan) }\end{array}$ \\
\hline Oxygen & $\left(\mu \mathrm{mol} \mathrm{kg}{ }^{-1}\right)$ & $339.7 \pm 1.7$ & $309.7 \pm 6.2$ & $191.0 \pm 2.3$ & $191.5 \pm 3.3$ \\
\hline & $\left(\mu \mathrm{mol} \mathrm{kg}{ }^{-1}\right)$ & $2167.1 \pm 5.1$ & $2210.2 \pm 4.5$ & $2270.6 \pm 2.7$ & $2271.4 \pm 4.7$ \\
\hline Salinity & & $33.845 \pm 0.074$ & & $34.679 \pm 0.006$ & \\
\hline \multicolumn{6}{|c|}{ Salinity normalized } \\
\hline Nitrate & $\left(\mu \mathrm{mol} \mathrm{kg}{ }^{-1}\right)$ & $25.1 \pm 0.44$ & & $35.2 \pm 1.80$ & \\
\hline Phosphate & $\left(\mu \mathrm{mol} \mathrm{kg}{ }^{-1}\right)$ & $1.73 \pm 0.07$ & & $2.4 \pm 0.03$ & \\
\hline DIC & $\left(\mu \mathrm{mol} \mathrm{kg}{ }^{-1}\right)$ & $2241.4 \pm 8.4$ & & $2289.3 \pm 4.2$ & \\
\hline
\end{tabular}

a Bottom: Salinity-normalized (multiplied by $35 / \mathrm{Sal}$ ) mean concentrations of nutrients and DIC for the same water masses for April. January data taken from cruise 740H20081226; April data taken from from cruise 74JC20100319.

of the time series, wintertime sea-to-air fluxes eclipse summer air-to-sea fluxes, while for the latter part, the reverse is true. This indicates substantial variability in the net annual carbon flux signal [Landschützer et al., 2014a]. The shaded areas represent the best estimate of the uncertainty of the monthly fluxes, derived by combining the error estimates of measurements, gridding, mapping, and gas transfer velocities. They characterize both the subregional variability observed within the box (Figure 4) and inherent within the predictive parameter fields and the uncertainty associated with deriving flux estimates from limited spatial and temporal data availability. On a global scale, gas exchange is the predominating contributor to the overall uncertainty [Landschützer et al., 2014a]. In the Weddell Gyre, however, the data residual will be at least as significant due to reduced data availability and autocorrelation associated with this smaller, highly variable region. Average monthly flux terms were calculated for the 14 year time series, as well as for the shorter period spanning the hydrographic measurements (2008-2010; shaded in Figure 5a). These are shown in Figure $5 \mathrm{~b}$ alongside their $95 \%$ confidence intervals (shaded) and the best estimate of the overall uncertainty of the neural network methodology. The relatively large mean uptake for the ANDREX period previously noted is apparent here. The greatest uncertainty for both long and short time spans occurs in the late summer and autumn and is likely related to the temporal variability associated with the timing and size of biological production, wind-driven mixed layer deepening, and the return of sea ice coverage. The larger uncertainty for the longer time series represents the variability in the timing of these events. Superimposed are the air-sea flux terms from the ocean inversion for the ANDREX and GLODAP data. They compare well with the sea-surface $\mathrm{pCO}_{2}$-derived summer fluxes. Both indicate that the resultant uptake fluxes of 0.044 to $0.058 \pm 0.010 \mathrm{PgC} \mathrm{yr}^{-1}$ correspond well to summer conditions. The annual means were calculated from both the full (1998-2011) and truncated (2008-2010) data sets, giving net uptakes of $0.002 \pm 0.007 \mathrm{PgC} \mathrm{yr}^{-1}$ and $0.012 \pm 0.024 \mathrm{PgC} \mathrm{yr}^{-1}$, respectively (where the uncertainty is the $95 \%$ confidence interval), suggesting a negligible to small annual $\mathrm{CO}_{2}$ sink status for the region.

\subsection{Surface Carbon Balance}

The seasonal signals presented have shown the importance of entrainment and biological production on surface DIC concentrations and the direction of the flux between the atmosphere and the ocean. Following Hoppema et al. [1999], the summer-winter differences in oxygen, salinity, and nutrient concentrations in source WDW and surface waters across the period of sea ice coverage are analyzed to infer net changes in DIC.

Oxygen values from Table 2 are applied to equation (1) to estimate the mean WDW fraction. These are taken from the subsurface temperature maximum for WDW (averaged from the two cruises along the northern boundary of the gyre) and stations $72-78$ for the post-sea-ice surface layer (covered by sea ice $\sim 1$ week prior to sampling in early January [Nolin et al., 1998]) and stations 62-68 for the pre-sea-ice conditions (an approximately 4 week gap before complete coverage in mid-May). A mean WDW fraction entraining into the mixed layer of $0.202 \pm 0.054$ is calculated for the end of winter. Assuming a mean mixed layer depth of $100 \mathrm{~m}$ (average calculated from ANDREX CTD profiles, also Hoppema et al. [1999]), 20.2\% or $20 \pm 5 \mathrm{~m}$ of the surface layer is thus renewed by "pure" WDW each year, equating to a mean entrainment age of $5.0 \pm 1.4$ years. The uncertainty estimate does not cover a number of aspects, such as the nonconsecutive nature of the data, changes that have occurred between sampling, and the onset/retreat of sea ice and interannual variability. 
Table 3. Net Annual Biological Consumption of Nutrients and DIC Calculated Using Remineralization Ratios ${ }^{a}$

\begin{tabular}{|c|c|c|c|c|}
\hline & \multirow{2}{*}{$\begin{array}{l}\text { Net Annual Biological Nutrient } \\
\text { Consumption } \\
\left(\mu \mathrm{mol} \mathrm{kg}{ }^{-1} \mathrm{yr}^{-1}\right)\end{array}$} & \multicolumn{2}{|c|}{$\begin{array}{l}\text { Net Annual Biological } \\
\text { Carbon Consumption } \\
\left(\mu \mathrm{mol} \mathrm{kg}{ }^{-1} \mathrm{yr}^{-1}\right)\end{array}$} & \multirow{2}{*}{$\begin{array}{c}\text { Mean Annual Biological Carbon } \\
\text { Consumption } \\
\left(\mu \mathrm{mol} \mathrm{kg}{ }^{-1} \mathrm{yr}^{-1}\right)\end{array}$} \\
\hline & & Redfield et al. [1963] & Anderson and Sarmiento [1994] & \\
\hline \multirow{3}{*}{ Nitrate } & & $R_{\mathrm{C}: \mathrm{N}} 6.6$ & $R_{\mathrm{C}: \mathrm{N}} 7.3$ & $14.5 \pm 2.2$ \\
\hline & $2.03 \pm 0.37$ & $13.4 \pm 2.5$ & $14.8 \pm 2.7$ & \\
\hline & & $R_{\mathrm{C}: \mathrm{P}} 106$ & $R_{\mathrm{C}: \mathrm{P}} 117$ & \\
\hline Phosphate & $0.13 \pm 0.02$ & $14.1 \pm 1.7$ & $15.6 \pm 1.8$ & \\
\hline
\end{tabular}

${ }^{a}$ Consumption values come from comparing surface layer and $W D W$ values and dividing by the surface layer renewal rate. The mean annual biological carbon consumption is the mean of the four values for the net annual biological carbon consumption.

However, effects are thought to be small as the pre-sea-ice oxygen concentrations are close to/at saturation and the timing of sea ice retreat occurred shortly before sampling.

The annual increase in surface layer DIC levels due to entrainment is reached using equation (1) and the entrainment rate. Substituting prewinter surface layer $[\mathrm{X}]_{\mathrm{SL} 1}$ and $W D W$ carbon data from Table 2 yields a presummer surface layer DIC $[X]_{S L 2}$ value of $2188.1 \mu \mathrm{mol} \mathrm{kg}{ }^{-1}$. Comparing with the prewinter surface concentration of $2167.1 \mu \mathrm{mol} \mathrm{kg}{ }^{-1}$ implies a net increase in DIC of $20.9 \pm 1.6 \mu \mathrm{mol} \mathrm{kg}^{-1} \mathrm{yr}^{-1}$ due to WDW entrainment. Repeating the process for salinity, an increase of 0.169 from 33.845 (prewinter) to 34.014 after entrainment is expected. To calculate the effects of the summer freshening, a prewinter DIC concentration unaffected by salinity changes can be calculated as $2167.1 \cdot(34.014 / 33.845)=2177.9 \mu \mathrm{mol} \mathrm{kg}{ }^{-1}$. This means that the annual freshening of the surface layer reduces the DIC concentration by $2177.9-2167.1=10.8 \pm 0.3 \mu \mathrm{mol} \mathrm{kg}^{-1} \mathrm{yr}^{-1}$. Combined, the net annual entrainment/freshening signal of DIC is $+10.1 \pm 1.5 \mu \mathrm{mol} \mathrm{kg}^{-1} \mathrm{yr}^{-1}$.

The effect of biological consumption or net community production was estimated by comparing the salinitynormalized concentrations of nitrate and phosphate in the surface layer with those in WDW and division by the surface layer renewal rate (Table 2). Decreases of $2.03 \pm 0.37 \mu \mathrm{mol} \mathrm{kg}{ }^{-1} \mathrm{yr}^{-1}$ and $0.13 \pm 0.02 \mu \mathrm{mol} \mathrm{kg}^{-1} \mathrm{yr}^{-1}$ were calculated for nitrate and phosphate, respectively. The effect of this biological activity on DIC levels can be estimated using nutrient changes in combination with suitable remineralization ratios (e.g., Redfield stoichiometry). We follow Hoppema et al. [1999] by applying both classical Redfield ratios [Redfield et al., 1963] and more recent approximations [Anderson and Sarmiento, 1994] commonly used in the region [Hoppema, 2004a; Hoppema et al., 2002; Lo Monaco et al., 2005; van Heuven et al., 2011] on both nitrate and phosphate depletion rates and calculate a mean annual biological carbon consumption of $14.5 \pm 2.2 \mu \mathrm{mol} \mathrm{kg}^{-1} \mathrm{yr}^{-1}$ (Table 3). Figure 5b summarizes the processes of the surface layer DIC balance budget and signals a residual term of $-4.3 \pm 2.7 \mu \mathrm{mol} \mathrm{kg}^{-1} \mathrm{yr}^{-1}$. Combining a mixed layer depth of $100 \mathrm{~m}$ and a Weddell region surface area of $6.2 \times 10^{12} \mathrm{~m}^{2}$, a net annual air-sea $\mathrm{CO}_{2}$ flux into the ocean of $0.033 \pm 0.021 \mathrm{PgC} \mathrm{yr}^{-1}$ is calculated. This compares well to the annual sink of $0.012 \pm 0.024 \mathrm{PgC} \mathrm{yr}^{-1}$ derived from neural network sea surface $\Delta p \mathrm{CO}_{2}$ estimates for the 2008-2010 period. This is not entirely unexpected as a significant amount of smoothing is involved in both methods: the multiyear mean annual cycle from the neural network approach removes part of the monthly and seasonal variabilities, while the use of chemical properties from the times of onset and retreat of sea ice similarly integrates the variability of the key processes affecting DIC levels, deconvolving the larger-scale response over time.

The impact of end-member selection and the representativeness of the northern part of the gyre for the region as a whole are tested by the substitution of the mean WDW characteristics with those taken from alternative Weddell Gyre locations, namely, the western Weddell Sea (1996 SR04 section), central Weddell Sea (2010 $0^{\circ} \mathrm{E}$ section), and the eastern boundary (2008 I06S occupation). Propagation of substituted oxygen values ( 187.6 to $195.2 \mu \mathrm{mol} \mathrm{kg}{ }^{-1}$ ) through the calculation scheme generates mean entrainment ages ranging from 4.74 to 5.25 years, within the uncertainty estimate presented here. Inclusion of alternate WDW DIC levels ( 2258.0 to $2268.7 \mu \mathrm{mol} \mathrm{kg}^{-1}$ ) produces a net change in surface DIC levels through entrainment of 17.9 to $20.4 \mu \mathrm{mol} \mathrm{kg}^{-1} \mathrm{yr}^{-1}$, compared to $20.9 \pm 1.6 \mu \mathrm{mol} \mathrm{kg}^{-1} \mathrm{yr}^{-1}$ for the northern gyre end-member. For the effects of freshening, substitute salinity values (34.654 to 34.688) elicit a DIC change of -10.2 to $-11.0 \mu \mathrm{mol} \mathrm{kg} \mathrm{yr}^{-1}$, compared to the $-10.8 \pm 0.3 \mu \mathrm{mol} \mathrm{kg}^{-1} \mathrm{yr}^{-1}$ originally calculated. Finally, the use of distinct salinity-normalized nutrients (nitrate at 33.3 to $34.7 \mu \mathrm{mol} \mathrm{kg}^{-1}$ and phosphate at 2.30 to 
$2.41 \mu \mathrm{mol} \mathrm{kg}{ }^{-1}$ ) and DIC (2280.7 to $2289.1 \mu \mathrm{mol} \mathrm{kg}^{-1}$ ) produces estimates of DIC change caused by biological activity of -11.9 to $-14.2 \mu \mathrm{mol} \mathrm{kg}{ }^{-1} \mathrm{yr}^{-1}$, in comparison to a northern end-member-derived value of $-14.5 \pm 2.2 \mu \mathrm{mol} \mathrm{kg}^{-1} \mathrm{yr}^{-1}$. Brought together within the surface layer budget, the residual air-sea $\mathrm{CO}_{2}$ exchange term is calculated to be -3.5 to $-5.0 \pm 2.2 \mu \mathrm{mol} \mathrm{kg}^{-1} \mathrm{yr}^{-1}$, equivalent to 0.027 to $0.038 \mathrm{PgC}^{-1}$. Although there are some variabilities between the individual outputs, due to the internal compensation and balancing nature of the transformations, the resultant derived air-sea $\mathrm{CO}_{2}$ flux is consistent and the methodology is robust to WDW end-member selection.

\section{Discussion}

\subsection{Ocean Transports}

The combination of observed interior carbon distributions with an estimate of the underlying circulation reveals the enormous quantities of carbon involved in regional horizontal transports and the relatively small net air-sea exchange that evolves from them. Water mass transformation enables the conversion of warm, salty WDW to colder, fresher WW and WSDW and WSBW (Table 1). This dual-cell overturning circulation [Jullion et al., 2014] is manifested by open-ocean wind-forced upwelling of WDW into the surface layer and downwelling (through cooling and salinity-derived buoyancy losses) at the gyre boundaries. Regional carbon dynamics are intrinsically linked to these processes, with the carbon signal associated with WDW entrainment dampening the annual $\mathrm{CO}_{2}$ sink capacity of the surface ocean and making the area a source of $\mathrm{CO}_{2}$ to the atmosphere for half of the year (Figures 3 and 5). Vertical transport estimates from the box inversion apportion a gyre interior upwelling of $2 \pm-2 \mathrm{~Sv}$ into the winter surface layer [Jullion et al., 2014] that equates to a flux of $1.8 \mathrm{PgC} \mathrm{yr}^{-1}$ (assuming a DIC concentration of $2271 \mu \mathrm{mol} \mathrm{kg}^{-1}$ in WDW). This compares well with a previous estimate of midgyre upwelling of $1.6 \mathrm{PgC} \mathrm{yr}^{-1}$ [Hoppema et al., 1999] for the Weddell Sea only. While a small fraction of the entrained signal is outgassed within the gyre during winter, a significant proportion exits the region to the east of Elephant Island (around stations 4 and 5; Figure 3a), where it enters the ACC's frontal system or participates in deepwater formation at the gyre's periphery ( 8 Sv [Jullion et al., 2014], 7.3 Pg C $\left.\mathrm{yr}^{-1}\right)$ and contributes to a net $A A B W$ (WSDW and WSBW) export of $-3.7 \mathrm{PgC}^{-1}$. Part of this signal derives from the sea ice pump, where DIC is added to the shelf waters as they become more dense by freshwater removal and brine rejection during sea ice formation. The remainder is derived directly from WDW as it is entrained by the dense waters descending the western and southwestern continental shelves. Both processes contribute to the region's importance for the removal of carbon dioxide from contact with the atmosphere and injection to the global abyss on climatically important time scales [Hoppema, 2004a; Marinov et al., 2006].

\subsection{Air-Sea $\mathrm{CO}_{2}$ Flux}

Due to low data coverage across the Southern Ocean, few alternative direct air-sea $\mathrm{CO}_{2}$ flux estimates for the Weddell region are available with which to compare the values calculated here and larger-scale estimates that do exist show significant variability. The area southwest of the SR04 line between Joinville Island and Kapp Norvegia-accounting for $\sim 27 \%$ of the surface area of the ANDREX region surface area-is assessed as a small net annual sink (-0.01 $\mathrm{PgC} \mathrm{yr}^{-1}$ [Hoppema et al., 1999; Stoll et al., 1999], using surface $p \mathrm{CO}_{2}$ measurements and entrainment rates, fitting well with our estimates from a greater area. Meanwhile, more extensive circumpolar studies show contrasting tendencies: south of $58^{\circ} \mathrm{S}$ (where $96 \%$ of the study box lies), sea surface $p \mathrm{CO}_{2}$ observations [Takahashi et al., 2009] and atmospheric inversions [Peylin et al., 2013] indicate a small $\mathrm{CO}_{2}$ source of $+0.04 \pm 0.02 \mathrm{PgC} \mathrm{yr}^{-1}$ and $+0.03 \pm 0.03 \mathrm{PgC} \mathrm{yr}^{-1}$, respectively; ocean biogeochemical models prescribe a negligible sink of $-0.04 \pm 0.09 \mathrm{Pg} \mathrm{Cyr}^{-1}$ [Lenton et al., 2013], while ocean inversions suggest a higher carbon uptake of $-0.07 \pm 0.01 \mathrm{PgC} \mathrm{yr}^{-1}$ [Lenton et al., 2013] or $-0.21 \pm 0.08 \mathrm{PgC} \mathrm{yr}^{-1}$ [Gruber et al., 2009] depending on weightings applied. Regarding the neural network methodology applied to estimate the fluxes in the Weddell region, it was found that the approach reproduces the available data well, with an overall small bias and similar uncertainty in predicted values to the much wider scale global analysis. However, the paucity of spatial and temporal data in this relatively small but highly variable region leads to a large overall uncertainty in integrated fluxes, where it is thought that data residuals contribute at least as much to the overall uncertainty as the error in gas exchange. The estimation of the contribution of individual drivers to the uncertainty is even less straightforward, mainly due to cross correlations within the predictors; e.g., variabilities (seasonal and interannual) in mixed layer depth are correlated to temperature variabilities. 


\subsection{Surface Layer Carbon Balance}

A comparison of outputs from the surface layer carbon balance method for data from 1993 to 1996 from the center of the Weddell Gyre [Hoppema et al., 1999] yields different estimates for the magnitude of the individual budget terms. The WDW entrainment rate of $35 \pm 10 \mathrm{~m} \mathrm{yr}^{-1}$ found by Hoppema et al. [1999] is higher than the $20 \pm 5 \mathrm{~m} \mathrm{yr}^{-1}$ presented here and is likely related to the greater divergent wind stress field and upwelling strength toward the center of the gyre. Additional upwelling estimates of $17 \mathrm{~m} \mathrm{yr}^{-1}$ [Gordon et al., 1984] and $44 \mathrm{~m} \mathrm{yr}^{-1}$ [Gordon and Huber, 1990] suggest that our outputs are at the lower end of the range. The variability observed in these upwelling estimates is largely thought to be reflective of the different locations and times of observations and how short-term variability impacts the local calculation of the mixed layer depth. DIC changes due to entrainment reflect these differing replenishment rates with a historical value of $+26 \mu \mathrm{mol} \mathrm{kg}^{-1} \mathrm{yr}^{-1}$ [Hoppema et al., 1999] compared to the new $+21 \mu \mathrm{mol} \mathrm{kg}^{-1} \mathrm{yr}^{-1}$ signal here. Freshwater dilution effects show high coherence between the two studies $\left(-11\right.$ and $\left.-10.8 \mu \mathrm{mol} \mathrm{kg}^{-1} \mathrm{yr}^{-1}\right)$, but differences are apparent in the biological production signals: higher historical nutrient consumptions (2.81 versus $2.03 \mu \mathrm{mol} \mathrm{kg}{ }^{-1} \mathrm{yr}^{-1}$ for nitrate and 0.18 versus $0.13 \mu \mathrm{mol} \mathrm{kg}^{-1} \mathrm{yr}^{-1}$ for phosphate) lead to a larger estimate of the biological pump $\left(-19.9 \pm 2.4 \mu \mathrm{mol} \mathrm{kg}{ }^{-1} \mathrm{yr}^{-1}\right.$ versus $\left.-14.5 \pm 2.2 \mu \mathrm{mol} \mathrm{kg}^{-1} \mathrm{yr}^{-1}\right)$ for Hoppema et al. [1999] and this study, respectively, caused mainly by the different entrainment estimates. These values translate to an annual biological production in the Weddell region of $0.14 \mathrm{PgC} \mathrm{yr}^{-1}$ [Smith, 1991], 0.17 $\mathrm{PgC} \mathrm{yr}^{-1}$ [Chavez and Toggweiler, 1995], $0.13 \pm 0.02 \mathrm{Pg} \mathrm{Cyr}^{-1}$ [Hoppema et al., 2002], and 0.18-0.25 $\mathrm{Pg} \mathrm{Cyr}^{-1}$ [Moreau et al., 2013]. The $0.11 \mathrm{PgC} \mathrm{yr}^{-1}$ of this study lies at the lower end of published estimates but is comparable with the broader range within the uncertainty margins. The range of estimates will likely be an indication of the natural interannual and spatial variabilities that will impact individual studies to different extents. The studies by Hoppema et al. [1999] and this study have similar residuals (air-sea $\mathrm{CO}_{2}$ uptake) of $3.6 \pm 3.3 \mu \mathrm{mol} \mathrm{kg} \mathrm{yr}^{-1}$ [Hoppema et al., 1999] and $4.3 \pm 2.7 \mu \mathrm{mol} \mathrm{kg}^{-1} \mathrm{yr}^{-1}$ (ANDREX). An air-sea $\mathrm{CO}_{2}$ uptake of $-0.008 \pm 0.007 \mathrm{PgC} \mathrm{yr}^{-1}$ is calculated for the southwestern sector of the Weddell region (area $\sim 1.7 \times 10^{12} \mathrm{~m}^{2}$ ), and extrapolating this to the full domain (area $\sim 6.2 \times 10^{12} \mathrm{~m}^{2}$ ) yields an annual uptake estimate of $-0.028 \pm 0.024 \mathrm{PgC} \mathrm{yr}^{-1}$. This compares well with the estimate of $-0.033 \pm 0.021 \mathrm{PgC}^{-1}$. The neural network estimate of $0.012 \pm 0.024 \mathrm{PgC} \mathrm{yr}^{-1}$ is also within their respective error bounds.

\section{Conclusions}

Three independent methods have been used to ascertain the magnitude and direction of the air-sea carbon dioxide flux in the Weddell region. The application of an ocean inversion technique [Jullion et al., 2014] to hydrographic data from around the boundary of the Weddell Gyre reveals a carbon budget that is sensitive to the underlying circulation scheme, with deepwater mass transports of WDW and WSBW dominating. A dual-cell vertical overturning circulation leads to both significant upwelling and the delivery of large quantities of carbon to the deep ocean, culminating in a net export of $3.7 \mathrm{PgC} \mathrm{yr}^{-1}$ of carbon in $A A B W$ (comprising WSDW and WSBW) from the region (Table 1), and a substantial transferral $\left(\sim 5 \mathrm{PgC}^{-1}\right)$ of carbon in WSDW across the South Scotia Ridge into the global abyssal oceans. The budget residual suggests an air-to-sea carbon flux for the summer months that is relatively insensitive to the source of input carbon data (ANDREX or GLODAP). A comparison with historical sea surface $f \mathrm{CO}_{2}$ observations from the SOCAT database [Bakker et al., 2014] interpolated using a two-step neural-network-based technique [Landschützer et al., 2014a] confirms the summertime carbon sink quantified in the ocean inversion (Figure 5b). It also reveals a similarly sized outgassing signal for the winter months. Combined together, the $p \mathrm{CO}_{2}$ fields diagnose a negligible to small annual carbon sink for the region, in line with previous estimates for the circumpolar Southern Ocean region of this latitude range [Gruber et al., 2009; Lenton et al., 2013; Peylin et al., 2013]. However, the strong seasonal and interannual variations also imply sensitivity of carbon fluxes to both short- and long-term variations in factors, such as changes in wind stress, sea ice coverage, and heat and freshwater fluxes [Lenton et al., 2013]. On an annual time scale, a surface layer carbon budget confirms that the Weddell region acts as a small atmospheric carbon sink. A breakdown of processes indicates that although strong entrainment of $W D W$ into the surface layer raises dissolved inorganic carbon levels during winter, the effects of freshwater inputs and biological production in summer on carbon drawdown exceed those of entrainment (Figure 6).

The Weddell region carbon sink is small in relation to the estimates of net global ocean carbon

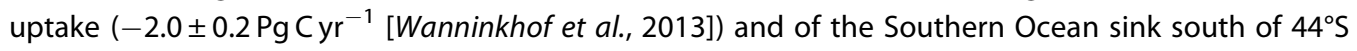




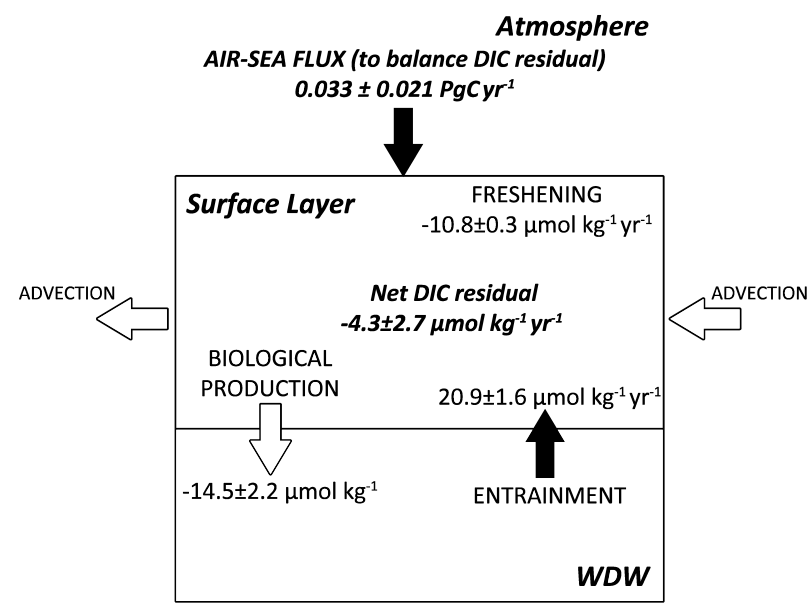

Figure 6. Annual surface layer carbon balance. Air-sea exchange reflects the Weddell region (area $6.2 \times 10^{12} \mathrm{~m}^{2}$ ). The positive (negative) values indicate the flux into (out of) the surface layer.

shallow depths $(<800 \mathrm{~m})$ in the Wedd
Gyre, and the buildup of dissolved inorganic carbon and coincident decrease in oxygen lead to the formation of a variant of WDW (named Central Intermediate Water by Hoppema et al. [2002]) that is too dense to mix with shelf waters. With only $\sim 20 \%$ of these waters believed to ultimately enter the surface layer, the vast majority exits the region northward entering the deep ACC, acting as an important conduit for transporting natural carbon away from the surface to the deep ocean [Hoppema et al., 2002]. The increase of $8 \mu \mathrm{mol} \mathrm{kg}^{-1}$ in the mean DIC concentration of WDW between entering the gyre as part of the Antarctic Slope Front at $30^{\circ} \mathrm{E}$ and leaving at the Weddell Front at $\sim 25^{\circ} \mathrm{W}$ (Figure 1) exemplifies this process. Finally, dense water production and ventilation in the western and southern parts of the gyre transfer large quantities of climatically important gases (e.g., anthropogenic carbon and chlorofluorocarbons (CFCs)) to the abyssal ocean on long time scales. This is evidenced by the buildup of dissolved inorganic carbon [van Heuven et al., 2011] and CFCs [Huhn et al., 2013] in deepwater masses in the region, the large net carbon export of WSDW and WSBW (Table 1), and their spreading northward along the ocean abyss [Orsi et al., 1999; Ríos et al., 2012].

With increasing atmospheric $\mathrm{CO}_{2}$ levels and a steady state ocean, the region would be expected to become more important globally, with upwelling-associated carbon outgassing progressively suppressed and deep waters carrying ever increasing anthropogenic carbon loadings [Lovenduski and Ito, 2009; Matear and Lenton, 2008]. However, given the sensitivity of the carbon fluxes to the horizontal and vertical overturning circulations, it is not known how the ocean physics or chemistry of the region will respond in an era of an accelerating hydrological cycle, increased glacial export, changing sea ice extent, wind stress trends, and warming shelf waters. The budgets determined here represent an important regional benchmark against which future changes can be compared and highlight critical processes that must be included if predictive skill concerning future change is to be increased.

\section{References}

Anderson, L. A., and J. L. Sarmiento (1994), Redfield ratios of remineralization determined by nutrient data analysis, Global Biogeochem. Cycles, 8, 65-80, doi:10.1029/93GB03318.

Anderson, R. F., S. Ali, L. I. Bradtmiller, S. H. H. Nielsen, M. Q. Fleisher, B. E. Anderson, and L. H. Burckle (2009), Wind-driven upwelling in the Southern Ocean and the deglacial rise in atmospheric $\mathrm{CO}_{2}$, Science, 323(5920), 1443-1448.

Atlas, R., R. N. Hoffman, J. Ardizzone, S. M. Leidner, J. C. Jusem, D. K. Smith, and D. Gombos (2011), A cross-calibrated, multiplatform ocean surface wind velocity product for meteorological and oceanographic applications, Bull. Am. Meteorol. Soc., 92(2), $157-174$.

Bacon, S., and L. Jullion (2009), RRS James Cook: Antarctic deep water rates of export (ANDREX), Tech. Rep. 08, Natl. Oceanogr. Cent., Southampton, U. K.

Bakker, D. C. E., H. J. W. de Baar, and U. V. Bathmann (1997), Changes of carbon dioxide in surface waters during spring in the Southern Ocean, Deep Sea Res., Part II, 44(1-2), 91-127, doi:10.1016/s0967-0645(96)00075-6.

Bakker, D. C. E., M. Hoppema, M. Schröder, W. Geibert, and H. J. W. de Baar (2008), A rapid transition from ice covered $\mathrm{CO}_{2}$-rich waters to a biologically mediated $\mathrm{CO}_{2}$ sink in the eastern Weddell Gyre, Biogeosciences, 5, 1373-1386.

Bakker, D. C. E., et al. (2014), An update to the surface ocean $\mathrm{CO}_{2}$ Atlas (SOCAT version 2), Earth Syst. Sci. Data, 6(1), 69-90, doi:10.5194/ essd-6-69-2014.

Bellerby, R. G. J., M. Hoppema, E. Fahrbach, H. J. W. de Baar, and M. H. C. Stoll (2004), Interannual controls on Weddell Sea surface water fCO during the autumn-winter transition phase, Deep Sea Res., Part I, 51, 793-808, doi:10.1016/j.dsr.2004.01.002. 
Brown, P. J., M. P. Meredith, L. Jullion, A. N. Garabato, S. Torres-Valdes, P. Holland, M. J. Leng, and H. Venables (2014), Freshwater fluxes in the Weddell Gyre: Results from delta O-18, Philos. Trans. R. Soc. A, 372(2019), doi:10.1098/Rsta.2013.0298.

Chavez, F. P., and J. R. Toggweiler (1995), Physical estimates of global new production: The upwelling contribution, in Upwelling in the Ocean: Modern Processes and Ancient Records, edited by C. P. Summerhayes et al., pp. 313-320, John Wiley, Chichester, U. K.

Dickson, A., J. Afghan, and G. Anderson (2003), Reference materials for oceanic $\mathrm{CO}_{2}$ analysis: A method for the certification of total alkalinity, Mar. Chem., 80, 185-197.

Fahrbach, E. (2006), The Expedition ANTARKTIS-XXII/3 of the Research Vessel "Polarstern" in 2005, Rep, Ber. Polar Meeresforsch., vol. 533, pp. 1-246, Alfred-Wegener-Institut, Bremerhaven, Germany.

Foldvik, A., T. Gammelsrød, and T. Törresen (1985), Circulation and water masses on the southern Weddell Sea shelf, in Oceanology of the Antarctic Continental Shelf, Antarct. Res. Ser., edited by S. S. Jacobs and R. F. Weiss, pp. 5-20, AGU, Washington, D. C.

Foster, T. D., and E. C. Carmack (1976), Frontal zone mixing and Antarctic bottom-water formation in the southern Weddell Sea, Deep Sea Res. 23, 301-317.

Fransson, A., M. Chierici, P. L. Yager, and W. O. Smith (2011), Antarctic sea ice carbon dioxide system and controls, J. Geophys. Res., 116, C12035, doi:10.1029/2010JC006844.

Geibert, W., et al. (2010), High productivity in an ice melting hot spot at the eastern boundary of the Weddell Gyre, Global Biogeochem. Cycles, 24, GB3007, doi:10.1029/2009GB003657.

GLOBALVIEW-CO2 (2011), Cooperative Atmospheric Data Integration Project-Carbon dioxide, NOAA ESRL, Boulder, Colo. [Also available on Internet via anonymous FTP to ftp.cmdl.noaa.gov, Path: ccg/co2/GLOBALVIEW.]

Gordon, A. L., and B. A. Huber (1990), Southern Ocean winter mixed layer, J. Geophys. Res., 95, 11,655-11,672, doi:10.1029/JC095iC07p11655.

Gordon, A. L., C. T. A. Chen, and W. G. Metcalf (1984), Winter mixed layer entrainment of Weddell Deep Water, J. Geophys. Res., 89, 637-640, doi:10.1029/JC089iC01 p00637.

Gouretski, V. V., and K. P. Koltermann (2004), WOCE global hydrographic climatology—A technical report, Rep

Gruber, N., M. Gloor, S. E. M. Fletcher, S. C. Doney, S. Dutkiewicz, M. J. Follows, M. Gerber, A. R. Jacobson, and S. A. Mu (2009), Oceanic sources, sinks, and transport of atmospheric $\mathrm{CO}_{2}$, Global Biogeochem. Cycles, 23, GB1005, doi:10.1029/2008GB003349.

Hoppema, M. (2004a), Weddell Sea is a globally significant contributor to deep-sea sequestration of natural carbon dioxide, Deep Sea Res. Part I, 51, 1169-1177, doi:10.1016/j.dsr.2004.02.011.

Hoppema, M. (2004b), Weddell Sea turned from source to sink for atmospheric $\mathrm{CO}_{2}$ between pre-industrial time and present, Global Planet. Change, 40, 219-231, doi:10.1016/j.gloplacha.2003.08.001.

Hoppema, M., E. Fahrbach, M. H. C. Stoll, and H. J. W. de Baar (1999), Annual uptake of atmospheric $\mathrm{CO}_{2}$ by the Weddell Sea derived from a surface layer balance, including estimations of entrainment and new production, J. Mar. Syst., 19, 219-233, doi:10.1016/S0924-7963(98) 00091-8.

Hoppema, M., M. H. C. Stoll, and H. J. W. de Baar (2000), $\mathrm{CO}_{2}$ in the Weddell Gyre and Antarctic Circumpolar Current: Austral autumn and early winter, Mar. Chem., 72(2-4), 203-220.

Hoppema, M., O. Klatt, W. Roether, E. Fahrbach, K. Bulsiewicz, C. B. Rodehacke, and G. Rohardt (2001), Prominent renewal of Weddell Sea Deep Water from a remote source, J. Mar. Res., 59, 257-279, doi:10.1357/002224001762882655.

Hoppema, M., H. J. W. de Baar, E. Fahrbach, and R. G. J. Bellerby (2002), Renewal time and transport of unventilated Central Intermediate Water of the Weddell Sea derived from biogeochemical properties, J. Mar. Res., 60, 677-697, doi:10.1357/002224002762688696.

Huhn, O., M. Rhein, M. Hoppema, and S. van Heuven (2013), Decline of deep and bottom water ventilation and slowing down of anthropogenic carbon storage in the Weddell Sea, 1984-2011, Deep Sea Res., Part I, 76, 66-84, doi:10.1016/j.dsr.2013.01.005.

Hulth, S., A. Tengberg, A. Landén, and P. O. J. Hall (1997), Mineralization and burial of organic carbon in sediments of the southern Weddell Sea (Antarctica), Deep Sea Res., Part I, 44(6), 955-981, doi:10.1016/S0967-0637(96)00114-8.

Jabaud-Jan, A., N. Metzl, C. Brunet, A. Poisson, and B. Schauer (2004), Interannual variability of the carbon dioxide system in the southern Indian Ocean ( $\left.20^{\circ} \mathrm{S}-60^{\circ} \mathrm{S}\right)$ : The impact of a warm anomaly in austral summer 1998, Global Biogeochem. Cycles, 18, GB1042, doi:10.1029/ 2002 GB002017.

Jackett, D. R., and T. J. McDougall (1997), A neutral density variable for the world's oceans, J. Phys. Oceanogr., 27, 237-263.

Johnson, K. M., A. Körtzinger, L. Mintrop, J. C. Duinker, and D. W. R. Wallace (1999), Coulometric total carbon dioxide analysis for marine studies: Measurement and internal consistency of underway $\mathrm{TCO}_{2}$ concentrations, Mar. Chem., 67, 123-144.

Jullion, L., et al. (2014), The contribution of the Weddell Gyre to the lower limb of the global overturning circulation, J. Geophys. Res. Oceans, 119, 3357-3377, doi:10.1002/2013JC009725.

Kalnay, E., et al. (1996), The NCEP/NCAR 40 year reanalysis project, Bull. Am. Meteorol. Soc., 77(3), 437-471, doi:10.1175/1520-0477(1996) $077<0437:$ TNYRP $>2.0 . C O ; 2$

Key, R. M., A. Kozyr, C. Sabine, K. Lee, R. Wanninkhof, J. Bullister, R. Feely, F. Millero, C. Mordy, and T. Peng (2004), A global ocean carbon climatology: Results from Global Data Analysis Project (GLODAP), Global Biogeochem. Cycles, 18, GB4031, doi:10.1029/2004GB002247.

Key, R. M., et al. (2010), The CARINA data synthesis project: Introduction and overview, Earth Syst. Sci. Data, 2(1), 105-121, doi:10.5194/essd-2105-2010.

Khatiwala, S., F. Primeau, and T. Hall (2009), Reconstruction of the history of anthropogenic $\mathrm{CO}_{2}$ concentrations in the ocean, Nature, 462, 346-349, doi:10.1038/nature08526.

Khatiwala, S., et al. (2013), Global ocean storage of anthropogenic carbon, Biogeosciences, 10, 2169-2191, doi:10.5194/bg-10-2169-2013.

Körtzinger, A. (1999), Determination of carbon dioxide partial pressure $\left(\mathrm{pCO}_{2}\right)$, in Methods of Seawater Analysis, 3rd ed., edited by K. Grasshoff, K. Kremling, and M. Ehrhardt, Wiley-VCH Verlag GmbH, Weinheim, Germany, doi:10.1002/9783527613984.ch9.

Landschützer, P., N. Gruber, D. C. E. Bakker, U. Schuster, S. Nakaoka, M. R. Payne, T. P. Sasse, and J. Zeng (2013), A neural network-based estimate of the seasonal to inter-annual variability of the Atlantic Ocean carbon sink, Biogeosciences, 10(11), 7793-7815.

Landschützer, P., N. Gruber, D. C. E. Bakker, and U. Schuster (2014a), Recent variability of the global ocean carbon sink, Global Biogeochem. Cycles, 28, 927-949, doi:10.1002/2014GB004853.

Landschützer, P., N. Gruber, D. C. E. Bakker, and U. Schuster (2014b), An observation-based global monthly gridded sea surface $\mathrm{pCO}_{2}$ product from 1998 through 2011 and its monthly climatology, Carbon Dioxide Inf. Anal. Cent., Oak Ridge Natl. Lab., U.S. Dep. of Energy, Oak Ridge, Tenn. [Available at http://cdiac.ornl.gov/ftp/oceans/spco2_1998_2011_ETH_SOM-FFN, doi:10.3334/CDIAC/OTG. SPCO2_1998_2011_ETH_SOM-FFN.]

Lenton, A., et al. (2013), Sea-air $\mathrm{CO}_{2}$ fluxes in the Southern Ocean for the period of 1990-2009, Biogeosciences, 10(6), 4037-4054, doi:10.5194/ bg-10-4037-2013.

Lo Monaco, C., N. Metzl, A. Poisson, C. Brunet, and B. Schauer (2005), Anthropogenic $\mathrm{CO}_{2}$ in the Southern Ocean: Distribution and inventory at the Indian-Atlantic boundary (World Ocean Circulation Experiment line 16), J. Geophys. Res., 110, C06010, doi:10.1029/2004JC002643. 
Lovenduski, N. S., and T. Ito (2009), The future evolution of the Southern Ocean $\mathrm{CO}_{2}$ sink, J. Mar. Res., 67, 597-617, doi:10.1357/ 002224009791218832.

Lumpkin, R., and K. Speer (2007), Global ocean meridional overturning, J. Phys. Oceanogr., 37, 2550-2562, doi:10.1175/JPO3130.1.

Marinov, I., A. Gnanadesikan, J. Toggweiler, and J. Sarmiento (2006), The Southern Ocean biogeochemical divide, Nature, 441, 964-967, doi:10.1038/nature04883.

Matear, R. J., and A. Lenton (2008), Impact of historical climate change on the Southern Ocean carbon cycle, J. Clim., 21, 5820-5834, doi:10.1175/2008JCLI2194.1.

Mazloff, M. R., P. Heimbach, and C. Wunsch (2010), An eddy-permitting Southern Ocean state estimate, J. Phys. Oceanogr., 40(5), 880-899, doi:10.1175/2009JPO4236.1.

Menemenlis, D., J. Campin, P. Heimbach, C. Hill, T. Lee, A. Nguyen, M. Schodlock, and H. Zhang (2008), ECCO2: High-resolution global ocean and sea ice data synthesis, in Mercator Ocean Quarterly Newsletter, 31, pp. 13-21, Mercator Ocean, Ramonville-Saint-Agne, France.

Meredith, M. P. (2010), Cruise report: RRS James Clark Ross JR235/236/239, Tech. Rep. Rep., British Antarctic Survey.

Meredith, M. P., R. A. Locarnini, K. A. Van Scoy, A. J. Watson, K. J. Heywood, and B. A. King (2000), On the sources of Weddell Gyre Antarctic bottom water, J. Geophys. Res., 105, 1093-1104, doi:10.1029/1999JC900263.

Metzl, N., C. Beauverger, C. Brunet, C. Goyet, and A. Poisson (1991), Surface water carbon dioxide in the southwest Indian sector of the Southern Ocean: A highly variable $\mathrm{CO}_{2}$ source/sink region in summer, Mar. Chem., 35, 85-95.

Metzl, N., C. Brunet, A. Jabaudjan, A. Poisson, and B. Schauer (2006), Summer and winter air-sea $\mathrm{CO}_{2}$ fluxes in the Southern Ocean, Deep Sea Res., Part I, 53, 1548-1563, doi:10.1016/j.dsr.2006.07.006.

Mikaloff Fletcher, S. E., et al. (2006), Inverse estimates of anthropogenic $\mathrm{CO}_{2}$ uptake, transport, and storage by the ocean, Global Biogeochem. Cycles, 20, GB2002, doi:10.1029/2005GB002530.

Mikaloff Fletcher, S. E., et al. (2007), Inverse estimates of the oceanic sources and sinks of natural $\mathrm{CO}_{2}$ and the implied oceanic carbon transport, Global Biogeochem. Cycles, 21, GB1010, doi:10.1029/2006GB002751.

Mintrop, L. (2004), Versatile instruments for the determination of titration alkalinity. Manual for versions 3S and 3C, Rep.

Moreau, S., E. di Fiori, I. R. Schloss, G. O. Almandoz, J. L. Esteves, F. E. Paparazzo, and G. A. Ferreyra (2013), The role of phytoplankton composition and microbial community metabolism in sea-air Delta pCO2 variation in the Weddell Sea, Deep Sea Res., Part l, 82, 44-59, doi:10.1016/j.dsr.2013.07.010.

Naveira Garabato, A. C., E. L. McDonagh, D. P. Stevens, K. J. Heywood, and R. J. Sanders (2002), On the export of Antarctic Bottom Water from the Weddell Sea, Deep Sea Res., Part II, 49, 4715-4742, doi:10.1016/S0967-0645(02)00156-X.

Nicholls, K. W., S. Østerhus, K. Makinson, T. Gammelsrød, and E. Fahrbach (2009), Ice-ocean processes over the continental shelf of the Southern Weddell Sea, Antarctica: A review, Rev. Geophys., 47, RG3003, doi:10.1029/2007RG000250.

Nolin, A. W., R. Armstrong, and J. Maslanik (1998), Near-real-time SSM/I-SSMIS EASE-grid daily global ice concentration and snow extent, version 4, [NISE.002], NASA DAAC at the National Snow and Ice Data Center, Boulder, Colo.

Orsi, A. H., T. Whitworth, and W. D. Nowlin (1995), On the meridional extent and fronts of the Antarctic Circumpolar Current, Deep Sea Res., Part I, 42, 641-673.

Orsi, A. H., G. Johnson, and J. Bullister (1999), Circulation, mixing, and production of Antarctic Bottom Water, Prog. Oceanogr., 43, 55-109.

Orsi, A. H., W. M. Smethie Jr., and J. L. Bullister (2002), On the total input of Antarctic waters to the deep ocean: A preliminary estimate from chlorofluorocarbon measurements, J. Geophys. Res., 107(C8), 3122, doi:10.1029/2001JC000976.

Peylin, P., et al. (2013), Global atmospheric carbon budget: Results from an ensemble of atmospheric $\mathrm{CO}_{2}$ inversions, Biogeosciences, 10(10), 6699-6720, doi:10.5194/bg-10-6699-2013.

Rayner, N. A., D. E. Parker, E. B. Horton, C. K. Folland, L. V. Alexander, D. P. Rowell, E. C. Kent, and A. Kaplan (2003), Global analyses of sea surface temperature, sea ice, and night marine air temperature since the late nineteenth century, J. Geophys. Res., 108(D14), 4407, doi:10.1029/ 2002JD002670.

Redfield, A., B. Ketchum, and F. Richards (1963), The influence of organisms on the composition of sea-water, in The Sea, edited by M. N. Hill, pp. 27-77, Wiley-Interscience, New York.

Reynolds, R. W., N. A. Rayner, T. M. Smith, D. C. Stokes, and W. Wang (2002), An improved in situ and satellite SST analysis for climate, J. Clim., 15(13), 1609-1625.

Ríos, A. F., A. Velo, P. C. Pardo, M. Hoppema, and F. F. Pérez (2012), An update of anthropogenic $\mathrm{CO}_{2}$ storage rates in the western South Atlantic basin and the role of Antarctic Bottom Water, J. Mar. Syst., 94, 197-203, doi:10.1016/j.jmarsys.2011.11.023.

Robertson, J. E., and A. J. Watson (1995), A summer-time sink for atmospheric carbon dioxide in the Southern Ocean between $88^{\circ} \mathrm{W}$ and $80^{\circ} \mathrm{E}$, Deep Sea Res., Part II, 42(4-5), 1081-1091, doi:10.1016/0967-0645(95)00067-z.

Sallée, J.-B., R. J. Matear, S. R. Rintoul, and A. Lenton (2012), Localized subduction of anthropogenic carbon dioxide in the Southern Hemisphere oceans, Nat. Geosci., 5, 579-584, doi:10.1038/ngeo1523.

Sayles, F. L., W. R. Martin, Z. Chase, and R. F. Anderson (2001), Benthic remineralization and burial of biogenic SiO2, CaCO3, organic carbon, and detrital material in the Southern Ocean along a transect at $170^{\circ}$ west, Deep Sea Res., Part II, 48(19-20), 4323-4383, doi:10.1016/S09670645(01)00091-1.

Schodlok, M. P., H. H. Hellmer, and A. Beckmann (2002), On the transport, variability and origin of dense water masses crossing the South Scotia Ridge, Deep Sea Res., Part II, 49, 4807-4825.

Schröder, M., and E. Fahrbach (1999), On the structure and the transport of the eastern Weddell Gyre, Deep Sea Res., Part II, $46,501-527$.

Smith, W. O. (1991), Nutrient distributions and new production in polar regions: Parallels and contrasts between the Arctic and Antarctic, Mar. Chem., 35(1-4), 245-257.

Speer, K., and T. Dittmar (2008), Cruise report, RV Revelle, 33RR20080204, Tech. Rep., Florida State Univ.

Stoll, M., H. J. W. de Baar, M. Hoppema, and E. Fahrbach (1999), New early winter $\mathrm{fCO}_{2}$ data reveal continuous uptake of $\mathrm{CO}_{2}$ by the Weddell Sea, Tellus, Ser. B, 51, 679-687.

Sweeney, C., E. Gloor, A. R. Jacobson, R. M. Key, G. McKinley, J. L. Sarmiento, and R. Wanninkhof (2007), Constraining global air-sea gas exchange for $\mathrm{CO}_{2}$ with recent bomb ${ }^{14} \mathrm{C}$ measurements, Global Biogeochem. Cycles, 21, GB2015, doi:10.1029/2006GB002784.

Takahashi, T., et al. (2009), Climatological mean and decadal change in surface ocean $\mathrm{PCO}_{2}$, and net sea-air $\mathrm{CO}_{2}$ flux over the global oceans, Deep Sea Res., Part II, 56, 554-577, doi:10.1016/j.dsr2.2008.12.009.

Takahashi, T., S. C. Sutherland, and A. Kozyr (2014), Global ocean surface water partial pressure of CO2 database: Measurements performed during 1957-2013 (version 2013), ORNL/CDIAC-160, NDP-088(V2013), Carbon Dioxide Inf. Anal. Cent., Oak Ridge Natl. Lab., U.S. Dep. of Energy, Oak Ridge, Tenn.

Tanhua, T., S. van Heuven, R. M. Key, A. Velo, A. Olsen, and C. Schirnick (2010), Quality control procedures and methods of the CARINA database, Earth Syst. Sci. Data, 2(1), 35-49, doi:10.5194/essd-2-35-2010. 
Thoning, K. W., D. R. Kitzis, and A. Crotwell (2010), Atmospheric carbon dioxide dry air mole fractions from quasi-continuous measurements at Barrow, Alaska; Mauna Loa, Hawaii; American Samoa; and South Pole, 1973-2009, Version: 2010-07-14. [Available at ftp://ftp.cmdl.noaa. gov/ccg/co2/in-situ/.]

U.S. Department Commerce (2006), 2-minute gridded global telief data (ETOPO2v2), Natl. Oceanic and Atmos. Admin., Natl. Geophys. Data Cent. [Available at http://www.ngdc.noaa.gov/mgg/fliers/06mgg01.html.]

Usbeck, R., M. R. van der Loeff, M. Hoppema, and R. Schlitzer (2002), Shallow remineralization in the Weddell Gyre, Geochem. Geophys. Geosyst., 3(1), 1008, doi:10.1029/2001GC000182.

van Heuven, S. M. A. C., M. Hoppema, O. Huhn, H. A. Slagter, and H. J. W. de Baar (2011), Direct observation of increasing $\mathrm{CO}_{2}$ in the Weddell Gyre along the Prime Meridian during 1973-2008, Deep Sea Res., Part II, 58, 2613-2635, doi:10.1016/j.dsr2.2011.08.007.

Vázquez-Rodríguez, M., F. Touratier, C. Lo Monaco, D. W. Waugh, X. A. Padin, R. G. J. Bellerby, C. Goyet, N. Metzl, A. F. Ríos, and F. F. Pérez (2009), Anthropogenic carbon distributions in the Atlantic Ocean: Data-based estimates from the Arctic to the Antarctic, Biogeosciences, 6 , 439-451, doi:10.5194/bg-6-439-2009.

Wang, Q., S. Danilov, and J. Schröter (2009), Bottom water formation in the southern Weddell Sea and the influence of submarine ridges: Idealized numerical simulations, Ocean Model., 28(1-3), 50-59.

Wanninkhof, R. (1992), Relationship between wind speed and gas exchange over the ocean, J. Geophys. Res., 97, 7373-7382, doi:10.1029/ 92JC00188.

Wanninkhof, R., A. Dickson, and C. A. Carlson (2009), Carbon dioxide, hydrographic, and chemical data obtained during the R/V Roger Revelle cruise in the Indian Ocean on CLIVAR repeat hydrography sections I06S_2008 (February 4 to March 17, 2008), Carbon Dioxide Inf. Anal. Cent., Oak Ridge Natl. Lab., U.S. Dep. of Energy, Oak Ridge, Tenn. [Available at http://cdiac.ornl.gov/ftp/oceans/CLIVAR/I06S_2008.data/.]

Wanninkhof, R., et al. (2013), Global ocean carbon uptake: Magnitude, variability and trends, Biogeosciences, 10, 1983-2000, doi:10.5194/ bg-10-1983-2013.

Watson, A., and A. Naveira Garabato (2006), The role of Southern Ocean mixing and upwelling in glacial-interglacial atmospheric $\mathrm{CO}_{2}$ change, Tellus, Ser. B, 58, 73-87, doi:10.1111/j.1600-0889.2005.00167.x.

Wefer, G., and G. Fischer (1991), Annual primary production and export flux in the Southern Ocean from sediment trap data, Mar. Chem., 35(1-4), 597-613 